\title{
The Pro-Inflammatory Cytokines IL-1 $\beta$ and TNF $\alpha$ Are Neurotrophic for Enteric Neurons
}

\author{
P. -Y. Gougeon, Sandra Lourenssen, Tian Y. Han, Dileep G. Nair, Mark J. Ropeleski, and Michael G. Blennerhassett \\ Gastrointestinal Diseases Research Unit, Department of Medicine, Queen's University, Kingston, Ontario, Canada K7L 3N6
}

Intestinal inflammation causes initial axonal degeneration and neuronal death but subsequent axon outgrowth from surviving neurons restores innervation density to the target smooth muscle cells. Elsewhere, the pro-inflammatory cytokines TNF $\alpha$ and IL-1 $\beta$ cause neurotoxicity, leading us to test their role in promoting enteric neuron death. In a rat coculture model, TNF $\alpha$ or IL-1 $\beta$ did not affect neuron number but did promote significant neurite outgrowth to twofold that of control by $48 \mathrm{~h}$, while other cytokines (e.g., IL-4, TGF $\beta$ )

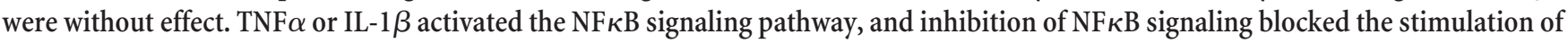
neurite growth. However, nuclear translocation of $\mathrm{NF} \kappa \mathrm{B}$ in smooth muscle cells but not in adjacent neurons suggested a dominant role for smooth muscle cells. TNF $\alpha$ or IL-1 $\beta$ sharply increased both mRNA and protein for GDNF, while the neurotrophic effects of TNF $\alpha$ or IL-1 $\beta$ were blocked by the RET-receptor blocker vandetanib. Conditioned medium from cytokine-treated smooth muscle cells mimicked the neurotrophic effect, inferring that TNF $\alpha$ and IL- $1 \beta$ promote neurite growth through NF $\kappa$ B-dependent induction of glial cell linederived neurotrophic factor (GDNF) expression in intestinal smooth muscle cells. In vivo, TNBS-colitis caused early nuclear translocation of NF $\kappa \mathrm{B}$ in smooth muscle cells. Conditioned medium from the intact smooth muscle of the inflamed colon caused a 2.5 -fold increase in neurite number in cocultures, while Western blotting showed a substantial increase in GDNF protein. Pro-inflammatory cytokines promote neurite growth through upregulation of GDNF, a novel process that may facilitate re-innervation of smooth muscle cells and a return to homeostasis following initial damage.

\section{Introduction}

Intestinal inflammation affects the enteric nervous system (ENS), causing altered motility and excessive fluid secretion. While typically transient in mild disease, more severe inflammation such as inflammatory bowel disease causes structural change (Vermeire et al., 2012). Understanding inflammation-induced damage to the ENS and the responses that facilitate repair is essential to improve treatment options. TNBS-induced colitis, a widely used model of Crohn's disease, causes the early partial loss of neurons and their axons from the ENS (Sanovic et al., 1999), and since the innervation of smooth muscle cells is linked to growth control (Lourenssen et al., 2005), this is in turn associated with smooth muscle cell growth. Interestingly, unclear repair processes then support the ENS even as inflammation worsens, with axon growth from surviving neurons quickly restoring the innervation density of smooth muscle despite smooth muscle hyperplasia

\footnotetext{
Received July 23, 2012; revised Dec. 13, 2012; accepted Dec. 22, 2012

Author contributions: P.-Y.G., S.L., M.J.R., and M.G.B. designed research; P.-Y.G., S.L., T.Y.H., D.G.N., and M.G.B. performed research; M.J.R. contributed unpublished reagents/analytic tools; P.-Y.G., S.L., and M.G.B. analyzed data; M.G.B. wrote the paper.

This work was supported by the Crohn's and Colitis Foundation of Canada and Natural Sciences and Engineering Research Council of Canada. P.-Y.G. was supported by a scholarship from the Canadian Association of Gastroenterology, Canadian Institutes of Health Research (CIHR), and Janssen-Ortho; T.Y.H. received a graduate scholarship from CIHR.

The authors declare no competing financial interests.

Correspondence should be addressed to Dr. M.G. Blennerhassett, Gastrointestinal Diseases Research Unit, Kingston General Hospital, Queen's University, 76 Stuart St, Kingston, Ontario, Canada K7L 3N6. E-mail: blennerm@queensu.ca.

DOI:10.1523/JNEUROSCI.3564-12.2013

Copyright $\odot 2013$ the authors $\quad 0270-6474 / 13 / 333339-13 \$ 15.00 / 0$
}

(Lourenssen et al., 2005). However, long-term or permanent changes remain in the intestine even after inflammation resolves, causing lasting dysmotility or promoting stricture formation (Verdu and Collins, 2005; Marlow and Blennerhassett, 2006).

Improved knowledge of the factors responsible for axonal growth could minimize the complications of an inflammatory episode. These include the neurotrophins involved in ontogeny such as glial cell line-derived neurotrophic factor (GDNF) (Uesaka et al., 2008) but also the inflammatory factors themselves (Schmitt et al., 2010; Boato et al., 2011). While typically detrimental to inflamed tissue and implicated in neurodegeneration (Smith et al., 2012), the latter also promotes neuroprotection and axon regeneration. For example, TNF $\alpha$ can prevent neurite outgrowth in the CNS (Neumann et al., 2002), but is also associated with axonal regeneration, promoting regrowth of transected optic nerves (Schwartz et al., 1991). Similarly, IL-1 $\beta$ mediates the loss of hippocampal neurons (Lu et al., 2005) but can also be neuroprotective (Carlson et al., 1999; Diem et al., 2003) or even promote neurite outgrowth from the damaged sciatic nerve (Temporin et al., 2008).

The receptors for pro-inflammatory cytokines are expressed by most cells and mediate wide-ranging alterations (Dinarello, 2010), so that such cytokines might either cause harm to the ENS or even promote the axonal growth observed in TNBS-colitis. With little data available, we studied this in a coculture model of rat intestinal myenteric neurons, glia, and smooth muscle cells (Blennerhassett and Lourenssen, 2000; Lourenssen et al., 2009, 2010), which allows examination of the factors affecting the development and maintenance of innervation of target smooth 
muscle cells. Since these neurons were recently found to be responsive to GDNF (Rodrigues et al., 2011), with evidence of the importance of GDNF for postnatal enteric neurons in vivo (Wang et al., 2010), identification of fundamental interactions between neurotrophins and inflammatory agents would be important for both current understanding of intestinal pathology as well as new drug development.

Here, we evaluate the ability of pro-inflammatory cytokines typically present during intestinal inflammation to affect neurite outgrowth. Surprisingly, the TH1 cytokines TNF $\alpha$ and IL- $1 \beta$ were uniquely able to potentiate this, whereas IL-4, IL-6, IL-10, TGF- $\beta$, or IFN- $\gamma$ was without effect. Furthermore, we identify the intestinal smooth muscle cell as a requisite intermediate, induced by TH1 cytokines to express increased GDNF via selective activation of the NF $\kappa \mathrm{B}$ pathway.

\section{Materials and Methods}

Cell culture. Intestinal tissue was isolated from neonatal rats of either sex according to previously described methods (Lourenssen et al., 2009), at postnatal Day 3 (conditioned media experiments), Day 4 (cytokine experiments), or Day 5 (experiments involving vandetanib). The muscularis externa was incubated in $0.25 \%$ trypsin II (Sigma) in HEPESbuffered Hanks' saline, pH 7.35, for 45-65 min, resuspended in medium (DMEM) containing $5 \%$ fetal calf serum (FCS) and triturated to yield a cell suspension that was plated onto glass coverslips previously coated with rat tail collagen I (0.002\%; Sigma). The medium was replaced $48 \mathrm{~h}$ later with serum-free DMEM, and cultures were incubated for a further $24 \mathrm{~h}$ before addition of cytokines or conditioned medium.

The cytokines TNF $\alpha$ or IL- $1 \beta(0.5-50 \mathrm{ng} / \mathrm{ml}$; Peprotech) were added to the cocultures daily for $24 \mathrm{~h}$ or $48 \mathrm{~h}$ and cells were processed for immunocytochemistry or Western blot analysis as described below. In some experiments, cocultures were treated similarly with IL-4, IL-6, IL10 , TGF $\beta$, or IFN $\gamma(50 \mathrm{ng} / \mathrm{ml}$ or $100 \mathrm{ng} / \mathrm{ml}$; Peprotech); cytokine concentrations were similar to those widely reported to be effective in vitro. To test the role of $\mathrm{NF} \kappa \mathrm{B}$ signaling in cytokine-induced neurite growth, the inhibitors SC-514 (50 $\mu \mathrm{M}$; Calbiochem) or Bay11-7082 (2.5 $\mu \mathrm{M}$; Santa Cruz Biotechnology) were added to the cocultures $1 \mathrm{~h}$ before cytokine addition, and cultures were fixed $24 \mathrm{~h}$ later and processed for immunocytochemistry to detect neurons and neurites as described below. In some experiments, cells were plated in DMEM alone with cytokines or GDNF added at the time of plating, with cultures being fixed $48 \mathrm{~h}$ later and processed for immunocytochemistry.

TNBS colitis. Adult male Sprague Dawley rats (250-350 g) were obtained from Charles River and housed in pairs in microfilter-isolated cages for at least $5 \mathrm{~d}$ before use with food and water ad libitum. Colitis was induced by instillation of $500 \mu \mathrm{l}$ of $200 \mathrm{~mm}$ trinitrobenzene sulfonic acid (Fluka) dissolved in $50 \%$ ethanol into the colon $8 \mathrm{~cm}$ proximal to the anus, under light anesthesia by inhalation of isoflurane as previously described (Wells and Blennerhassett, 2004). Animals were killed by cervical dislocation under isoflurane anesthesia at $2 \mathrm{~d}$ after the initiation of colitis. All procedures received prior approval by the University Animal Care Committee of Queen's University.

Conditioned medium experiments. To determine the potential contribution of the individual cell types to axonal remodeling in cocultures, donor cultures consisting of either cocultures, or pure cultures of intestinal glia or smooth muscle were generated in $35 \mathrm{~mm}$ dishes as described previously (Rodrigues et al., 2011). TNF $\alpha$ or IL-1 $\beta$ was added twice over a $30 \mathrm{~h}$ period, then medium was removed and replaced with fresh DMEM for $18 \mathrm{~h}$ to generate conditioned medium. This was added to naive recipient cocultures daily for $2 \mathrm{~d}$. Recipient cocultures were incubated for a further $24 \mathrm{~h}$ after the last addition of conditioned medium, then fixed and processed for assessment of neuron and neurite number as described below.

In some experiments, vandetanib ( $1 \mu \mathrm{M}$; LC Laboratories) was added to the cocultures just before addition of conditioned medium, TNF $\alpha$, or IL- $1 \beta$. Vandetanib is a multitargeted tyrosine kinase inhibitor of the RET receptor (Houvras, 2012), verified to inhibit the action of GDNF in vitro through comparison against GDNF-neutralizing antibodies (data not shown). Addition of GDNF ( $50 \mathrm{ng} / \mathrm{ml}$ ) to some cocultures was included as a positive control. After $24 \mathrm{~h}$, cocultures were fixed and processed as above.

For ex vivo conditioned medium, the smooth/muscle myenteric plexus was removed from the colons of animals administered TNBS $2 \mathrm{~d}$ previously. Intact pieces $(0.5 \mathrm{~cm}$ in length) were placed into $1 \mathrm{ml}$ of $0 \%$ DMEM for $24 \mathrm{~h}$ to generate conditioned medium, which was then added to established cocultures and incubated for a further $24 \mathrm{~h}$. In some experiments, cocultures were pretreated with TNF-R1 or IL1-R1 receptor antibodies (Santa Cruz Biotechnology G-20, 1:50 or H-150, 1:100, respectively) for $1 \mathrm{~h}$ before addition of medium. Cocultures were fixed $24 \mathrm{~h}$ later and processed for immunocytochemistry to detect neuron and neurite number as described below.

Peritoneal macrophages were prepared as described previously (Albina et al., 1991). Briefly, immune cells were removed from the peritoneum of an adult rat by sterile lavage, placed at $37 \mathrm{C}$ for $30 \mathrm{~min}$, and then added to transwells (Fisher) for $2 \mathrm{~h}$ to allow adherence of macrophages. The transwells were washed to remove lymphocytes and neutrophils and inserted into 24 -well plates containing cocultures that had been cultured for $2 \mathrm{~d}$ in $5 \%$ serum followed by $24 \mathrm{~h}$ in DMEM without serum. Cocultures were fixed $24 \mathrm{~h}$ later for determination of neuron and neurite number.

Immunocytochemistry and quantification. Immunocytochemistry was used to detect neurons and neurites as described previously (Lourenssen et al., 2009, 2010). Cultures were fixed for $10 \mathrm{~min}$ in $4 \%$ neutral buffered formalin and incubated overnight with antibodies to the neuronal protein $\mathrm{HuD}$ (1:1000; Invitrogen) or the pan-axonal marker SNAP-25 (1: 2000; Sigma). Previous work has shown that SNAP-25 will identify all neurites in vitro, verified using antibodies to PGP 9.5 or neuron-specific $\beta$-tubulin (data not shown); neurites are not specifically identified as axonal or dendritic in the current study. Following incubation for $2 \mathrm{~h}$ with fluorescent secondary antibodies (1:2000 Alexa 555-conjugated goat anti-rabbit IgG or Alexa 488 goat anti-mouse IgG; Invitrogen), staining was visualized for imaging and quantification by fluorescence microscopy (ImagePro Plus 6.0, Media Cybernetics; Olympus BX51).

To identify cells expressing receptors for TNF $\alpha$ and IL-1 $\beta$, cocultures were double labeled with antibodies to TNF-RI or IL-RI as well as with markers of glia (goat anti-SOX10; 1:8000; Santa Cruz Biotechnology or rabbit anti-S100; 1:10,000; Dako), neurons (mouse anti-HuD; 1:2000; Invitrogen), or smooth muscle (mouse anti- $\alpha$ SMA; 1:500; Dako).

To study the activation of the $\mathrm{NF} \kappa \mathrm{B}$ pathway in response to cytokine addition, cocultures were treated with IL- $1 \beta$, TNF $\alpha$, or TGF $\beta(50 \mathrm{ng} / \mathrm{ml})$ for 15 or $30 \mathrm{~min}$, and cells were fixed and colabeled with rabbit anti-p65NFkB (1:200; Santa Cruz Biotechnology) and either mouse anti-HuD, mouse anti$\alpha$ SMA, or goat anti-GFAP (1:1000; Santa Cruz Biotechnology).

The number of $\mathrm{HuD}$-positive neurons and SNAP-25-positive neurites present in coculture was determined as described previously (Lourenssen et al., 2010). Briefly, all the neurons in every third field of view from edge to edge of the midline of each culture were counted (60×, NA 1.20), which was then repeated in the perpendicular axis and represented $2 \%$ of the total area. Neuron number/coverslip (e.g., typically $14,500 \pm 35(n=6$ animals $))$ was then averaged over replicate coverslips (2-3/condition) within an experiment derived from a single animal to create one data point. Data are presented as the mean of at least three animals per experiment.

The abundance of neurites was quantified by counting the number of neurite intersections with an arbitrary midline intersector in the same regions as above, then multiplied to yield a value proportional to the number of neurites (Lourenssen et al., 2010). This value ("neurite number"; typically, $94 \pm 21$ ( $n=6)$ neurite intersections/coverslip) is proportional to the total neurite length in the culture and thus, after normalizing to neuron number, the average response of neurite outgrowth from all neurons can be compared under different conditions. In some cases, cocultures were colabeled with antibodies to $\mathrm{HuD}$ and nNOS (1:1000; Eurodiagnostica), and the number of nNOS-positive neurons and neurites was counted as above.

Proliferation assay. ${ }^{3} \mathrm{H}$-thymidine incorporation assays were used to evaluate the potential growth effect of cytokines on cocultures, glia, or 
smooth muscle cells as described previously (Blennerhassett and Lourenssen, 2000). Cultures were maintained in serum-free medium for $72 \mathrm{~h}$ before addition of IL- $1 \beta(25 \mathrm{ng} / \mathrm{ml})$ or TNF $\alpha(50 \mathrm{ng} / \mathrm{ml})$. Addition of $5 \%$ FCS was used as a positive control. ${ }^{3} \mathrm{H}$-thymidine was added $17 \mathrm{~h}$ later for $5 \mathrm{~h}$ before processing for determination of uptake by scintillation counting. Outcomes were normalized to cohort-negative controls and expressed as fold-increase over control.

Reverse-transcriptase PCR and quantitative real-time PCR. RNA was isolated from control or cytokine-treated cocultures using the RNAase-4PCR kit (Ambion) according to manufacturer's instructions. cDNA was generated and amplified from isolated RNA using RETROscript (Ambion) following manufacturer's suggested protocol. To detect TNFRI mRNA, the following primers were used: sense $5^{\prime}$-AATGGCACCGTGACAATCC-3' and antisense 5' CTGAAGGCTGGGATAGA-3' yielding a 377bp amplicon. To detect mRNA for IL-1R, the following primers were used: $5^{\prime}$-CCTGTGATTA TGAGCCCACG-3' and 5'-CGTGTGCAGTCTCCAGAATATG-3' yielding a $298 \mathrm{bp}$ amplicon. For detection of GAPDH, the following primers were used $5^{\prime}$-TGACAACTTTGGCATCGTGG- $3^{\prime}$ and $5^{\prime}$-TACTCCTTGG AGGCCATGT-3' yielding a $513 \mathrm{bp}$ amplicon. PCR products were resolved on a 1.5\% agarose gel, and imaged using an AlphaImager Tech EC (Fisher).

For quantitative real-time PCR (qPCR), total RNA from control or cytokine-treated cocultures was isolated using an RNeasy kit (Qiagen) according to the manufacturer's protocol. Then $1 \mu \mathrm{g}$ of total RNA was converted into cDNA using an iScript cDNA synthesis kit (Bio-Rad). cDNA (150-200 ng) was taken for qPCR using iTaq Fast SYBR Green supermix with ROX (Bio-Rad) (7500 Real-Time PCR instrument; Applied Biosystems). Primers were designed to yield short amplicons $(\sim 150$ bp) for $\mathrm{HuD}$ (forward, 5' -GCGCACACACATACACAAAAGAG-3'; and reverse, 5' -AATCCTTTCCTGGTACACCTCAG-3') and SNAP-25 (forward, $5^{\prime}$-AAATGATGCCCGAGAAAATG- ${ }^{\prime}$ and reverse $5^{\prime}$-CAGCAT CTTTGTTGCACGTT-3'). Primers for GDNF (forward, $5^{\prime}$-GACTCCAA TATGCCCGAAGA- $3^{\prime}$; and reverse, $5^{\prime}$-GTGGCTTGAATAAAATCCAT G-3';) and GAPDH (forward, 5' -TGCACCACCAACTGCTTAG- ${ }^{\prime}$ and reverse 5'-GATGCAGGGATGATGTTC-3') were also used. Dissociation curve analysis confirmed the specificity of amplification. RNA expression was determined based on the $\Delta \Delta \mathrm{Ct}$ comparative method of relative quantification according to 7500 System Sequence Detection Software v1.3. Results were expressed as fold-change relative to the control.

Western blot analysis. To determine TNF-R1 and IL1-R1 expression levels in cocultures, TNF $\alpha$ or IL- $1 \beta(50 \mathrm{ng} / \mathrm{ml})$ was added for $30 \mathrm{~min}$ or $4 \mathrm{~h}$, then cells were scraped off the plates using $0.2 \mathrm{ml}$ of $1 \times$ sample buffer (20 mu Tris, pH 6.8, 6\% glycerol, $0.6 \%$ SDS, $1.5 \% \beta$-mercaptoethanol, $0.75 \%$ bromophenol blue), sonicated for $20 \mathrm{~s}$, and stored at $4^{\circ} \mathrm{C}$. Aliquots (20 $\mu$ l per lane) were resolved by $12 \%$ SDS-PAGE, and transferred to PVDF/nitrocellulose membrane using a wet transfer apparatus (BioRad), blocked in 5\% nonfat milk in Tris-buffered saline containing $0.2 \%$ Tween 20 (TBS-T). Blots were incubated with antibodies to TNF-RI or IL1-RI in TBS-T (1:1000; Santa Cruz Biotechnology), followed by appropriate horseradish peroxidase-linked secondary antibodies, and then visualized using a chemiluminescent substrate (Super Signal; Pierce). These were reprobed with antibodies to $\alpha$-tubulin to confirm equal protein loading (1:5000; Sigma).

Alternatively, cultures were treated with cytokines ( $50 \mathrm{ng} / \mathrm{ml}$ ) for $15-$ $120 \mathrm{~min}$, and then processed for Western blot analysis to detect phosphorylated p65, ERK, and AKT (1:1000; Cell Signaling Technology). Signals were normalized to nonphosphorylated proteins (ERK, Akt; 1:1000; Cell Signaling Technology) or to $\beta$-actin (1:5000; Sigma).

To test for cytokine-induced production of GDNF protein, cell lysates were generated as above at $24 \mathrm{~h}$ post addition of TNF $\alpha$ or IL- $1 \beta$ ( 50 $\mathrm{ng} / \mathrm{ml}$ ). The supernatant from treated cultures was also tested for the presence of secreted growth factor. For this, supernatant was removed from the well before cell lysis, and trichloroacetic acid (Sigma) was added to a final concentration of $10 \%$ and incubated for $1 \mathrm{~h}$ on ice, then centrifuged at 13,000 rpm for $10 \mathrm{~min}$ to generate a pellet. The media was removed and replaced with $50 \mu \mathrm{l}$ of sample buffer. These were used for Western blot analysis to detect GDNF (1:1000; R\&D), followed by $\beta$-actin as for $\alpha$-tubulin above.
${ }^{3} \mathrm{H}$-ACh metabolism. Cocultures were treated with TNF $\alpha(50 \mathrm{ng} / \mathrm{ml})$ daily for $2 \mathrm{~d}$ following the protocol described above, then assessed for acetylcholine (ACh) synthesis and release as described earlier (Lourenssen et al., 2009; Rodrigues et al., 2011). For this, the media was removed from the wells and the cells washed with Krebs buffer consisting of the following (in mM): $25 \mathrm{NaHCO}_{3}, 118 \mathrm{NaCl}, 4.7 \mathrm{KCl}, 1 \mathrm{NaH}_{2} \mathrm{PO}_{4}, 1.2$ $\mathrm{MgSO}_{4}, 11$ glucose, and $2.5 \mathrm{CaCl}_{2}$, bubbled with $\left.95 \% \mathrm{O}_{2} / 5 \% \mathrm{CO}_{2}\right)$. Then $250 \mu \mathrm{l}$ of Krebs containing ${ }^{3} \mathrm{H}$-labeled choline (1:500 dilution of $1 \mu \mathrm{Ci}$ / $\mathrm{ml}$; GE Healthcare) was added to the cocultures and incubated for $1 \mathrm{~h}$ at $37^{\circ} \mathrm{C}$, followed by three washes in Krebs buffer. Krebs buffer containing $80 \mathrm{~mm} \mathrm{~K}^{+}$was then added for $5 \mathrm{~min}$. The cells were then washed, labeled, and choline was again added for $1 \mathrm{~h}$ at $37^{\circ} \mathrm{C}$. For each condition tested, half of the cultures were then treated with Krebs buffer containing $80 \mathrm{~mm}$ $\mathrm{K}^{+}$. The supernatant was then placed in scintillation vials for measurement of stimulated ${ }^{3} \mathrm{H}$-ACh release from the cells, and compared with the baseline leakage from unstimulated cultures. Then $400 \mu$ l of $10 \%$ SDS was added to each well and incubated for $15 \mathrm{~min}$ at room temperature. The cells were scraped off the wells and placed into scintillation vials for analysis of residual ${ }^{3} \mathrm{H}$. Specificity of the method was verified by addition of hemicholinium or veratridine to the cocultures before measurement of stimulated ${ }^{3} \mathrm{H}$-ACh release.

Chemicals. All chemicals were from Sigma unless specified otherwise.

Statistics. Values are expressed as the average \pm SEM $(n)$ animals. Statistical significance was assumed for $p \leq 0.05$ using one-way ANOVA.

\section{Results}

\section{Pro-inflammatory cytokines exert neurotrophic effects in vitro}

We first established the distribution of receptors for the prominent pro-inflammatory cytokines TNF $\alpha$ and IL-1 $\beta$ in the rat intestinal wall in vivo and on cultured cells in vitro. Immunocytochemistry showed that receptors for TNF $\alpha$ and IL- $1 \beta$ were present on multiple cell types in the normal colon, including intestinal smooth muscle cells in both circular and longitudinal layers, as well as neurons in the myenteric plexus (Fig. 1A,B). Primary cultures of the neonatal rat intestine, composed of myenteric neurons and intestinal smooth muscle cells ("cocultures"; Fig. $1 C, D$ ) showed widespread immunoreactivity for antibodies to these receptors (Fig. $1 E, F$ ).

To test whether these cytokines might be neurotoxic in vitro, as previously shown (Klegeris et al., 2007; Smith et al., 2012), cocultures were exposed to either one or both cytokines under serum-free conditions for $48 \mathrm{~h}$ and neuron number was evaluated by immunocytochemistry for the cell body marker, HuD. However, this showed no decrease in neuron number (Fig. 2A) and additional testing of other cytokines (TH1, TH2, or Treg) also showed no significant changes in neuron number (Fig. $2 B$ ).

Nonetheless, the exposure of the cocultures to either TNF $\alpha$ or IL- $1 \beta$ caused unexpected and striking changes: immunocytochemistry for the neurite marker SNAP-25 combined with the cell body marker HuD showed a greatly increased presence of neurites (Fig. $2 C, D$ ). Image analysis showed that treatment with TNF $\alpha$ or IL- $1 \beta$ caused a concentration-dependent increase in neurite number, to $162 \pm 27 \%$ and $228 \pm 31 \%$ relative to control, respectively $(p<0.05 ; 50 \mathrm{ng} / \mathrm{ml})$ (Fig. $2 E$ ). Other cytokines were ineffective, with neurite numbers similar to control after addition of IFN- $\gamma$, TGF- $\beta$, IL-4, IL-6, or IL-10, even at concentrations as high as $100 \mathrm{ng} / \mathrm{ml}$ (Fig. $2 F$ ). Thus, TNF $\alpha$ and IL- $1 \beta$ appeared to be unique in their ability to induce alterations in axon structure of cultured myenteric neurons.

\section{IL-1 $\beta$ and TNF $\alpha$ receptors are abundant and functional in vitro}

To identify the signaling cascades activated by cytokine addition to cocultures, we added IL- $1 \beta$ and TNF $\alpha$ for various times, fol- 

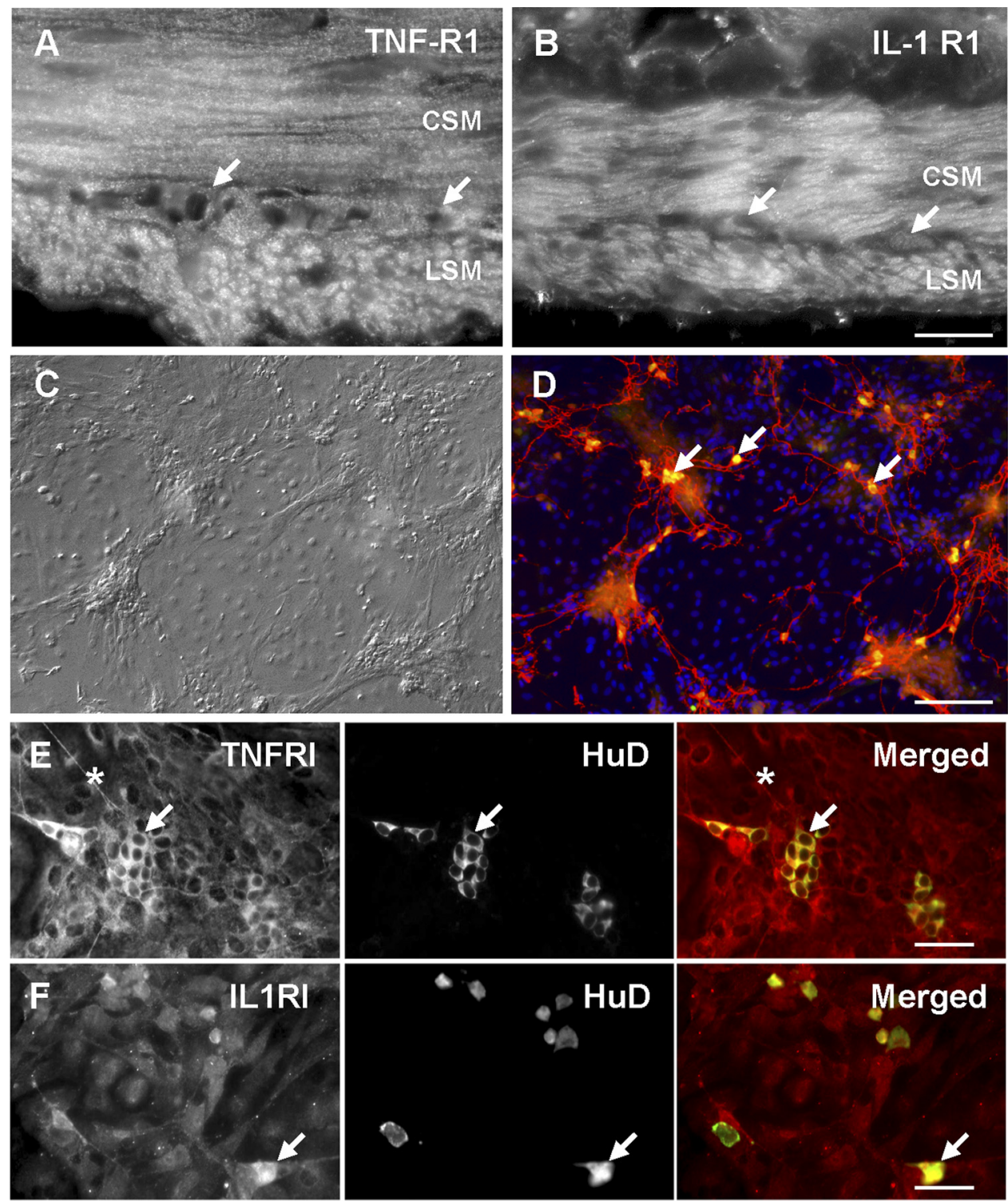

Figure 1. Receptors for the pro-inflammatory cytokines TNF $\alpha$ and IL-1 $\beta$ are present on cells of the smooth muscle/myenteric plexus layer in vivo and in vitro. $\boldsymbol{A}, \boldsymbol{B}$, Images of fluorescence immunocytochemistry showing the presence of staining for TNF-R1 $(\boldsymbol{A})$ and IL-1 R1 (B) on sections of control intestine. Staining was evident on smooth muscle cells of the CSM and longitudinal muscle (LSM) layers, as well as on neurons of the myenteric plexus (arrows). Scale bar, $100 \mu \mathrm{m}$. C, D, Depiction of the coculture model of myenteric neurons and intestinal smooth muscle cells. $\boldsymbol{C}$, Nomarski image of culture appearance at $7 \mathrm{~d}$ in vitro, showing complex architecture. $\boldsymbol{D}$, Fluorescence image of same field showing neurons and neurites among smooth muscle cells, as revealed by immunostaining for SNAP-25 (red) and the neuronal cell body marker HuD (green). Arrows indicate the location of neuronal cell bodies (yellow, merged color). Nuclei were stained with Hoechst (blue). Scale bar, $250 \mu \mathrm{m} . \boldsymbol{E}, \boldsymbol{F}$, Typical outcome of dual label immunocytochemistry showing expression of cytokine receptors on myenteric neurons in vitro. $\boldsymbol{E}$, Images of positive staining for TNF-RI and the neuronal marker HuD (arrows) and their overlap (merged). Asterisks $\left(^{*}\right)$ indicate neurites. $\boldsymbol{F}$, Similar outcome as $\boldsymbol{E}$ showing overlap of staining for IL1-RI with HuD (e.g., arrows). Scale bars, $100 \mu \mathrm{m}$.

lowed by Western blot analysis for signaling intermediates. Phosphorylation of p65/NF $\kappa \mathrm{B}$ occurred within 15 min of stimulation with either cytokine, and remained increased over control for at least $8 \mathrm{~h}$ (Fig. 3A). While phosphorylation of ERK also occurred by $15 \mathrm{~min}$ of cytokine stimulation, this was reduced to control levels at $4 \mathrm{~h}$ post-treatment with either cytokine. AKT phosphorylation was also evident by 15 min post-cytokine addition, and was maximal at $30 \mathrm{~min}$.

Since receptor endocytosis may occur in response to cytokine addition (Naismith and Sprang, 1998), we looked at relative TNF-RI and IL1-RI expression $30 \mathrm{~min}$ and $4 \mathrm{~h}$ after addition of $50 \mathrm{ng} / \mathrm{ml}$ of either TNF $\alpha$ or IL1 $\beta$. First, real time (RT)-PCR detected mRNA for both cytokine receptors in control cocultures, with no apparent change following treatment with either cytokine for up to $17 \mathrm{~h}$ (Fig. 3B). Similarly, Western blotting and analysis of protein band intensity showed no changes relative to control in response to either cytokine (Fig. $3 C$ ), suggesting that these receptor levels are not altered by ligand addition. In some experiments, cocultures were treated for $8 \mathrm{~h}$ with cytokines, then washed in DMEM $(0 \%)$ and fixed to assess for neuron and neurite number $16 \mathrm{~h}$ later, respectively. While treatment with TNF $\alpha$ for $8 \mathrm{~h}$ was insufficient to increase neurite number by $16 \mathrm{~h}$ post addition, similar treatment with IL- $1 \beta$ did cause a significant response, with neurite number increasing to $169 \pm 29 \%$ of control when analyzed $24 \mathrm{~h}$ later. Therefore, addition of these Th1 cytokines to cocultures leads to rapid and possibly sustained activation of signaling pathways that may culminate in neurite outgrowth. 

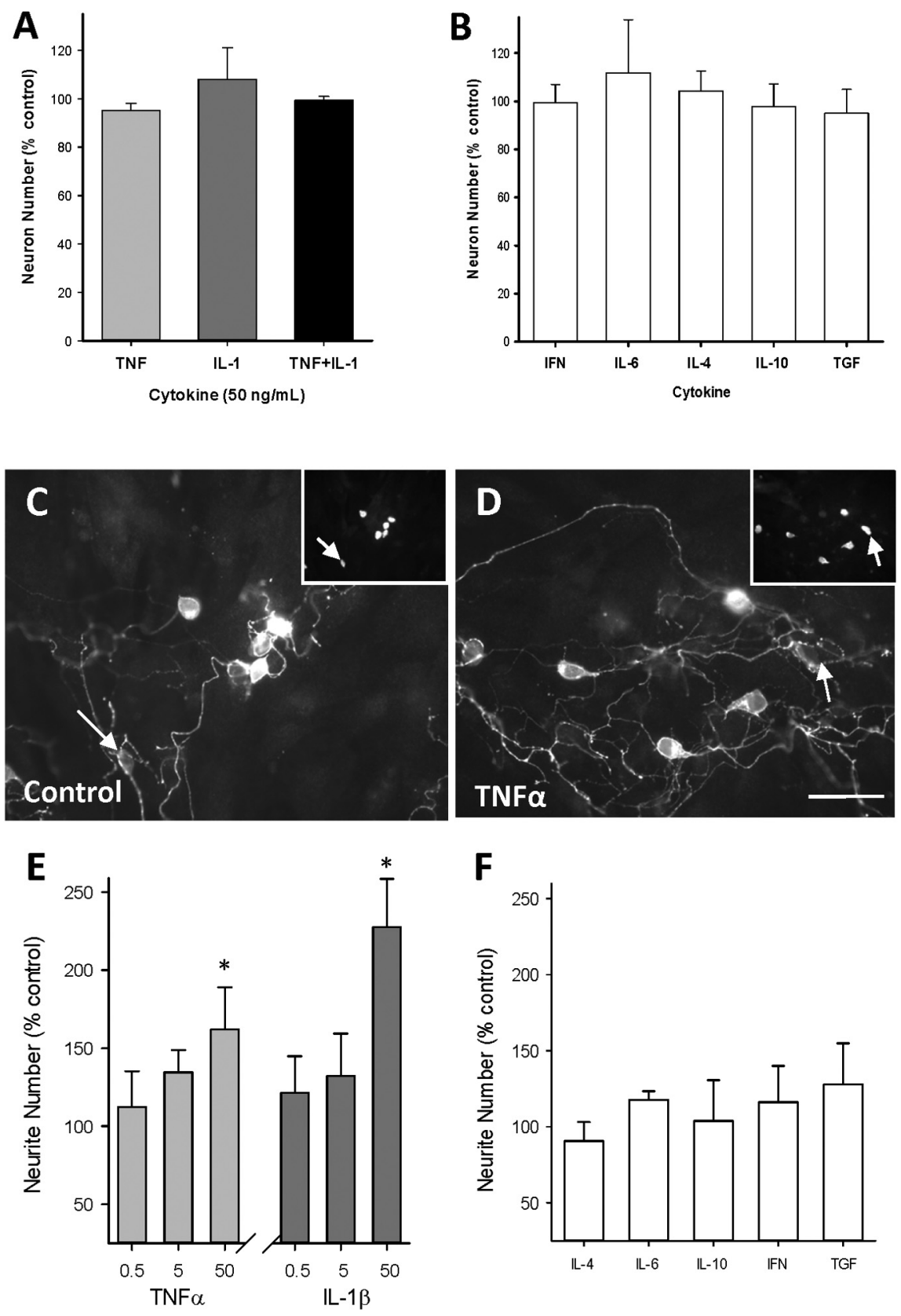

Figure 2. Pro-inflammatory cytokines are neurotrophic for myenteric neurons in vitro. $\boldsymbol{A}$, Neuron number was unchanged in cocultures treated with the pro-inflammatory cytokines TNF $\alpha$, IL-1 $\beta$, or a combination of both cytokines for $48 \mathrm{~h}(p>0.05 ; n=$ 9,8 , and 4). $\boldsymbol{B}$, No effect on neuronal survival with $48 \mathrm{~h}$ exposure to TH1 cytokines (IFN $\gamma$, IL-6), TH2 cytokines (IL-4, IL-10) at 100 $\mathrm{ng} / \mathrm{ml}$, or TGF $\beta(50 \mathrm{ng} / \mathrm{ml})(p>0.05, n=4)$. C, $\boldsymbol{D}$, Images showing increased neurite outgrowth caused by TNF $\alpha$ in vitro. Representative images of immunofluorescence outcomes of control coculture ( $\boldsymbol{C}$ ) and coculture treated with $50 \mathrm{ng} / \mathrm{ml}$ TNF $\alpha$ for $48 \mathrm{~h}$ (D) labeled with anti-SNAP-25 antibodies, showing large increase in neurite number with cytokine treatment. Inset, view of neuronal cell bodies in main panels from dual label immunocytochemistry for the neuronal cell body marker HuD. Arrows indicate representative neurons in each pair of images. Scale bar, $100 \mu \mathrm{m}$. $\boldsymbol{E}$, Quantification of neurite number in cocultures treated with TNF $\alpha$ or IL- $1 \beta$ for $48 \mathrm{~h}$ compared with untreated cohort controls, showing concentration-dependent increases in neurite number in each case $\left(n=3-9 ;{ }^{*} p<0.05\right)$. $F$, Absence of effect of IL-4, IL-6, IL-10, IFN- $\gamma(100 \mathrm{ng} / \mathrm{ml})$, or TGF $\beta$ (50 ng/ml) on neurite outgrowth in cocultures exposed to cytokines for $48 \mathrm{~h}$.

Since immunocytochemistry for the expression of TNF-RI and IL1-R1 showed strong labeling of cells in the cocultures, clearly including neurons as well as smooth muscle cells (Fig. $1 F$ ), multiple cell types could be potential targets for TNF $\alpha$ and IL1 $\beta$. The NF $\kappa \mathrm{B}$ pathway is an important mechanism for cytokine signaling in most cell types involving the nuclear translocation of p65/NF $\kappa$ B and subsequent gene transcription (for review, see-
Bowie and O'Neill, 2000). To determine which cells were acutely responsive to cytokine addition, cocultures were treated with TNF $\alpha$ or IL1 $\beta$ for $30 \mathrm{~min}$, followed by immunocytochemistry for $\mathrm{p} 65 / \mathrm{NF} \kappa \mathrm{B}$. This showed a distinct translocation to the nuclei of smooth muscle cells, in contrast to an unchanged cytoplasmic distribution in control cells or those treated with IL-6, IL-4, or IFN- $\gamma$ (Fig. 3D-I). However, in cultures treated with TNF $\alpha$ or IL- $1 \beta$, some cells consistently showed no response (Fig. 3 E, F, arrowheads). Dual-label immunocytochemistry and confocal microscopy showed that HuD-positive cells (i.e., myenteric neurons) showed no nuclear translocation of $\mathrm{p} 65 / \mathrm{NF} \kappa \mathrm{B}$ following exposure to TNF $\alpha$ or IL- $1 \beta$ (Fig. $4 A-F$ ). A similar approach showed the strongly positive accumulation of $\mathrm{p} 65 / \mathrm{NF} \kappa \mathrm{B}$ in the nuclei of $\alpha$-SM actin-expressing smooth muscle cells (Fig. 4G,H).

To confirm the involvement of the $\mathrm{NF} \kappa \mathrm{B}$ pathway in cytokine-induced neurite growth, we pretreated cocultures with two different inhibitors of this pathway before addition of TNF $\alpha$ or IL- $1 \beta$ for $24 \mathrm{~h}$, first verifying that each antagonist prevented the nuclear translocation of p65 and did not affect neuron number (data not shown). Addition of SC-514 (20 $\mu \mathrm{M})$ or Bay11-7082 (2.5 $\mu \mathrm{M})$ for $2 \mathrm{~h}$ before cytokine addition completely prevented the potentiating effect of cytokines on neurite growth (Fig. $5 A, B$ ).

\section{Axon outgrowth and neurotransmitter release}

Previously, prolonged addition of IL- $1 \beta$ to preparations of the guinea pig jejunum caused an increased representation of nitrergic neurons (Kindt et al., 2010), suggesting an effect on neuronal phenotype. Therefore, the proportion of nNOSpositive neurites was measured relative to total SNAP-25-positive axons in cytokinetreated cocultures. In control cocultures, nitrergic neurites comprised $48 \pm 2 \%$ of the total, and this remained unchanged at $48 \mathrm{~h}$ post-treatment with IL- $1 \beta$ or $\mathrm{TNF} \alpha$, respectively $(53 \pm 3 \%$ and $47 \pm 8 \%$ of control; $n=3$ per condition). Similarly, the ratio of nNOS-positive neuronal cell bodies relative to control did not change with cytokine treatment (data not shown). In light of nNOS expression being complementary to the expression of cholinergic markers in describing the entire neural population (Lourenssen et al., 2009), this is indirect evidence for a universal effect among the myenteric neurons.

The consequence of cytokine-induced neurite outgrowth was explored with real-time PCR to examine mRNA for SNAP-25, a synaptic vesicle protein with ubiquitous presence in the myenteric plexus in vitro (Lourenssen et al., 2009). This was expressed 
A
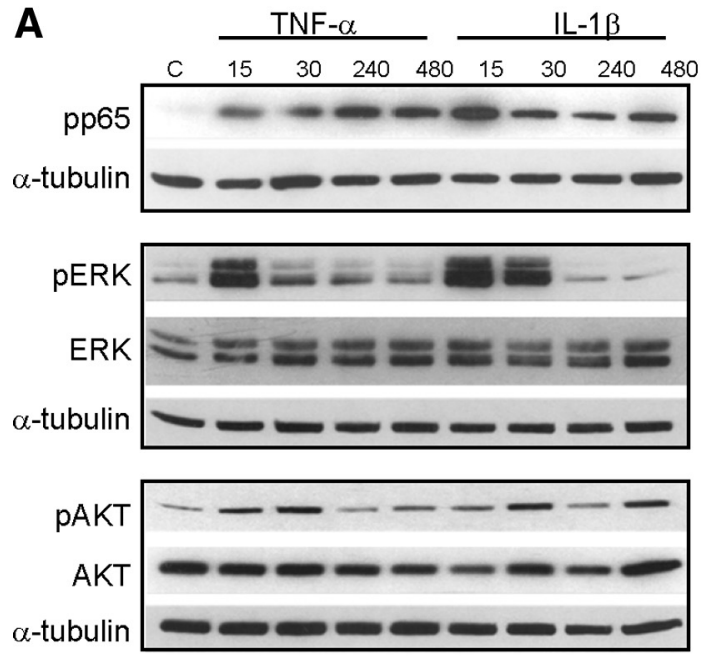

C

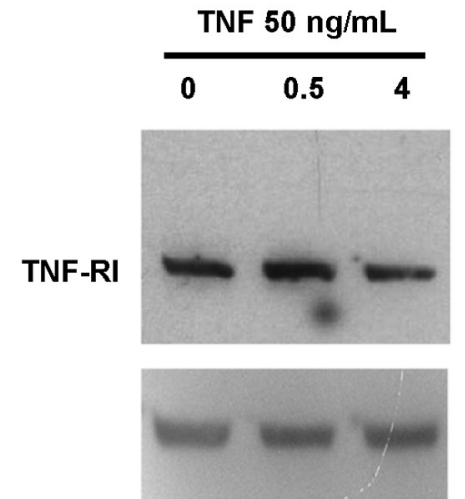

B
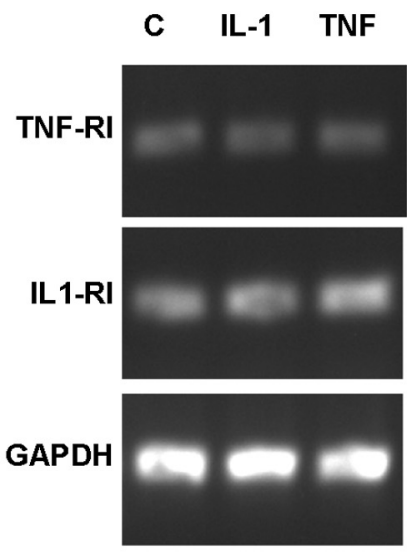

$\mathrm{IL}-150 \mathrm{ng} / \mathrm{mL}$

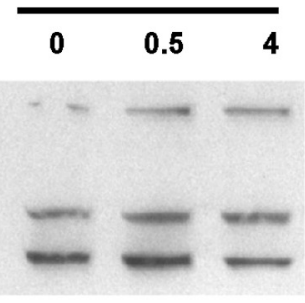

IL1-RI
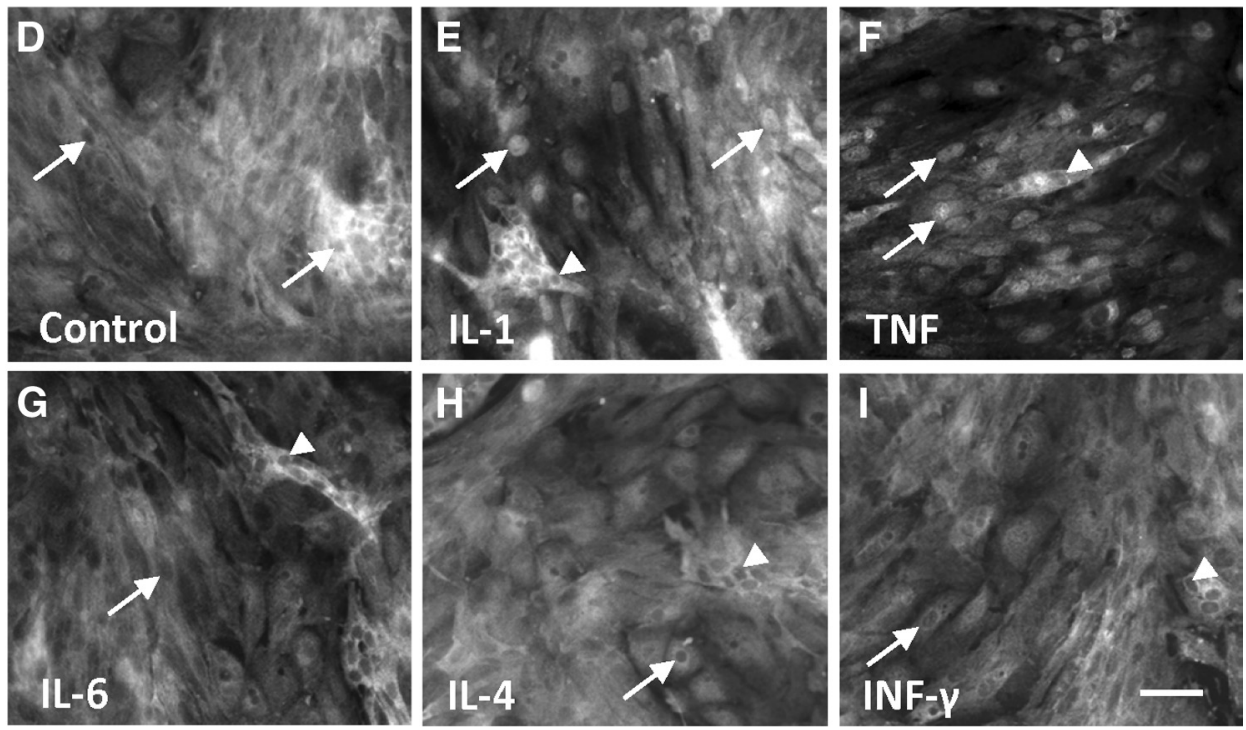

Figure 3. Receptors for TNF $\alpha$ and IL-1 $\beta$ are expressed in vitro and TNF $\alpha$ and IL-1 $\beta$, but not other cytokines, cause mobilization of p65/NF $\kappa$ B to the nucleus of smooth muscle cells. $A$, Representative Western immunoblot showing time course of phosphorylation of key intracellular intermediates following exposure of cocultures to TNF $\alpha$ or IL- $1 \beta$ ( $50 \mathrm{ng} / \mathrm{ml}$ ). A lasting phosphorylation of p65/NF $\kappa$ B was evident by 15 min, with simultaneous increased phosphorylation of both ERK and AKT. Maximal ERK phosphorylation occurred 15 min post-cytokine treatment, while maximum AKT phosphorylation was evident by 30 min post-cytokine addition. Antibodies to $\alpha$-tubulin, total ERK, and total AKT were used as loading controls. $B$, Representative image of RT-PCR showing mRNA levels for TNF-RI and IL1-RI in control cocultures, with no change at $17 \mathrm{~h}$ post-treatment with TNF $\alpha$ or IL-1 $\beta$ ( $50 \mathrm{ng} / \mathrm{ml})$ relative to control. Amplicon sizes were 377,298 , and 513 bp for TNF-R1, IL-1-R1, and GAPDH, respectively. C, Representative Western blots showing expression of cytokine receptors in intestinal cocultures were not altered by cytokine application. Left, The expression of TNFRI receptor was unaffected by 0.5 or $4 \mathrm{~h}$ of treatment with $50 \mathrm{ng} / \mathrm{ml}$ TNF $\alpha$. Similarly, the multiple bands representing IL-1R1 were not detectably altered by similar treatment with IL-1 $\beta$ (right). The loading control was $\alpha$-tubulin and the images shown are representative of three experiments. $D-I$, Immunocytochemistry showing mobilization of p65 to the nucleus of cells in cocultures exposed to TNF $\alpha$ or IL1 $\beta$, but not IL-4, IL-6, or IFN $\gamma$. Cohort cultures were exposed to cytokine for 30 min before fixation and staining. Positive outcomes were seen with IL-1 $\beta$ and TNF $\alpha$ $(\boldsymbol{E}, \boldsymbol{F}$; examples indicated by arrows) but not with other cytokines $(\mathbf{G}-\mathbf{l}$; arrows indicate typical negative outcomes). In all cases, clusters of cells interpreted as neurons were negative (e.g., arrowheads; see Fig. 4). Scale bar, $50 \mu \mathrm{m}$. 

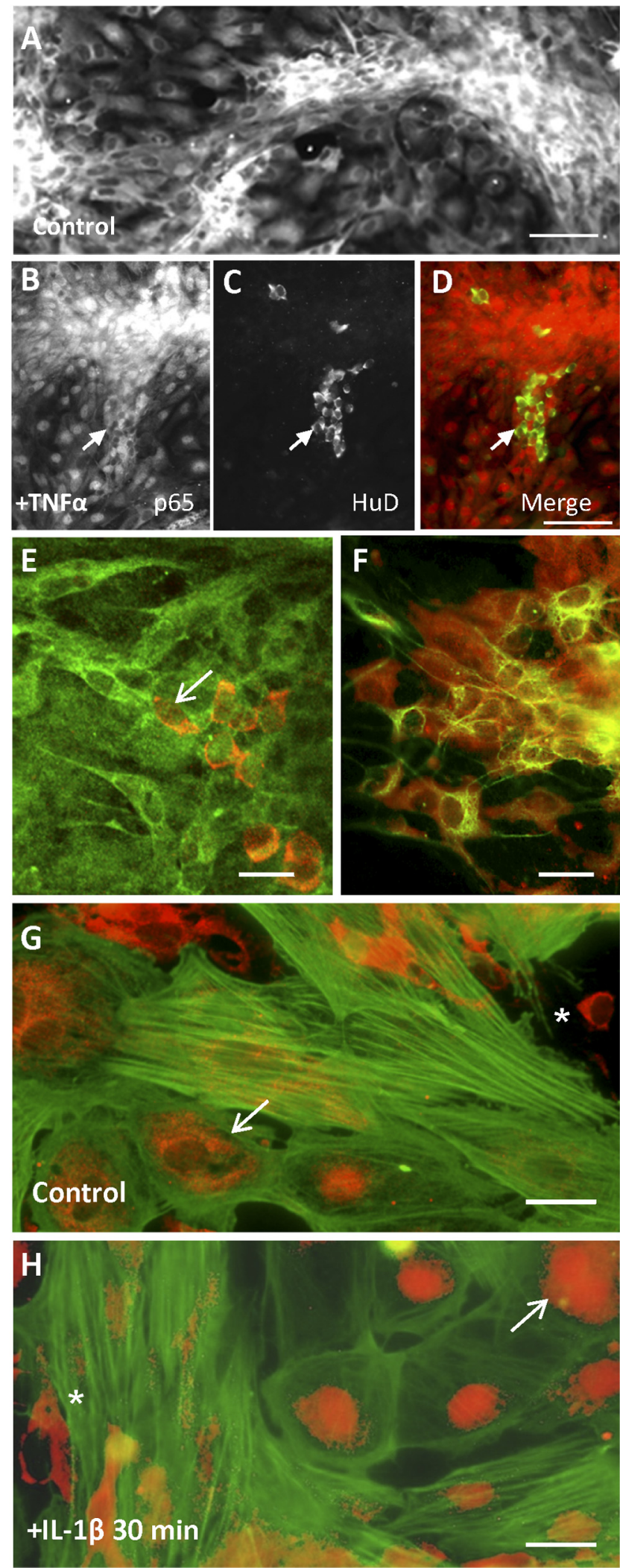

Figure 4. Immunocytochemistry for location of $p 65$ following cytokine treatment of cocultures, showing that activation and nuclear localization of $\mathrm{p} 65$ is selective among neurons, glia, and smooth muscle cells. A, Fluorescence micrograph of control appearance of p65 in cocultures, showing cytoplasmic localization without nuclear staining. Scale bar, $70 \mu \mathrm{m}$. $\boldsymbol{B}-\boldsymbol{D}$, Representative images showing strong localization of $p 65$ to the nuclei of the majority of cells in coculture by $120 \mathrm{~min}$ after addition of $\operatorname{TNF} \alpha(\boldsymbol{B})$. Nonresponsive cells (e.g., arrow) were identified as neurons by dual label immunocytochemistry for the cell body marker HuD ( $\boldsymbol{C}$, and relative to mRNA for the pan-neuronal marker $\mathrm{HuD}$ (since neuron number was stable), showing that mRNA for SNAP-25 increased by $3.8 \pm 1.4$ and $2.8 \pm 0.4$ fold over control after exposure to TNF $\alpha$ and IL-1 $\beta$, respectively. This potential for increased neurotransmitter storage and release was then assessed through examination of ACh metabolism, where we measured ${ }^{3} \mathrm{H}$ choline uptake and depolarization-induced ${ }^{3} \mathrm{H}$-ACh release as described earlier(Lourenssen et al., 2009). In cocultures treated with TNF $\alpha$ or IL- $1 \beta$ for 48 h, both cytokines caused large increases in the uptake of ${ }^{3} \mathrm{H}$-choline (25 and 50\% respectively; Fig. $5 C)$. Nonetheless, depolarization-induced release of ${ }^{3} \mathrm{H}-\mathrm{ACh}$ (expressed relative to precursor uptake) showed no significant increase in the presence of cytokine, with TNF $\alpha$ causing a significant decrease relative to untreated controls (Fig. 5D). Therefore, the increased amounts of neurite structure caused by exposure to these pro-inflammatory cytokines correlate with increased precursor uptake but not increased neurotransmitter release.

\section{The neurotrophic action of TNF $\alpha$ or IL-1 $\beta$ is indirect}

The critical role for the $\mathrm{NF} \kappa \mathrm{B}$ pathway and its activation in smooth muscle cells in cocultures suggested that the response of this cell type to specific cytokines could lead to enhanced neurite outgrowth in vitro. To test for the production of a diffusible factor, conditioned medium (CM) from cytokine-treated (donor) cultures was added to recipient cocultures, which were analyzed $24 \mathrm{~h}$ later. First, CM from cytokine-treated cocultures mimicked the effect of direct addition (Fig. 6A), thus identifying a diffusible and medium-borne factor. Pure cultures of intestinal circular smooth muscle cells (CSM) showed both cytokine-induced p65 translocation and a strong cytokine-dependent effect of their CM on neurite outgrowth (Fig. $6 B, C$ ). In control experiments, no nuclear translocation of p 65 was observed by 30 min post addition of cytokine-treated CM from CSM, indirect proof of transfer of a cytokine-free CM (data not shown). In contrast to CSM, the $\mathrm{CM}$ from pure cultures of enteric glia was ineffective in inducing significant neurite outgrowth, even with cytokine exposure (Fig. $6 D)$. We conclude that intestinal smooth muscle cells either in pure culture or in coculture were selectively responsive to TNF $\alpha$ or IL- $1 \beta$ by expressing a neurotrophic factor for myenteric neurons.

Since intestinal smooth muscle cells in cocultures expressed receptors for TNF $\alpha$ and IL- $1 \beta$, these cells might proliferate in response to cytokine stimulation, as seen previously (Libby et al., 1988; Yang et al., 2000). Thus, the cytokines could indirectly promote axon extension among an increasing target cell population. However, evaluation of ${ }^{3} \mathrm{H}$-thymidine incorporation in cocultures exposed to TNF $\alpha$ or IL-1 $\beta$ (50 ng/ml) using an established protocol (Stanzel et al., 2010; Nair et al., 2011) showed no increased cell proliferation, where these cytokines caused ${ }^{3} \mathrm{H}$-thymidine incorporation of $107 \pm 10 \%$ and $96 \pm 5 \%$ relative to control, respectively $(n=3 ; p>0.05$ relative to con-

$\leftarrow$

merged in $\boldsymbol{D}$ ). Scale bar, $200 \mu \mathrm{m}$. $\boldsymbol{E}$, Confocal micrograph showing absence of p65 staining (green) from the nuclei of neurons (HuD; red) in cocultures at 30 min following exposure to IL- $1 \alpha$. The arrow indicates a HuD-positive, p65-negative neuron, with some surrounding HuDnegative, p65-negative cells suggested to be glia. Scale bar, $30 \mu \mathrm{m}$. $\boldsymbol{F}$, Dual label immunocytochemistry showing absence of $\mathrm{p} 65$ mobilization (red) in enteric glia (GFAP; green) in a cohort coculture to $\boldsymbol{E}$. Scale bar, $30 \mu \mathrm{m} . \boldsymbol{G}, \boldsymbol{H}$, Identification of cytokine-induced nuclear localization of p65 in intestinal smooth muscle cells in coculture, identified by immunoreactivity for $\alpha$-SM actin (green). Control cells (G) showed cytoplasmic 065 staining (red; e.g., arrow) but acquired uniform, robust nuclear p65 staining by 30 min postexposure to IL-1 $\alpha$ (H; e.g., arrow). Note absence of response in $\alpha$-SM actin-negative cells (asterisk). Scale bars, $15 \mu \mathrm{m}$. 
trol). Since glia may also respond to cytokines by undergoing cell division, purified glial cultures were treated and evaluated similarly, and again showed no change compared with control (data not shown). Therefore, smooth muscle or glial cell hyperplasia is not involved in the increase in axon number in response to cytokine addition.

\section{Cytokines induce a diffusible neurotrophic factor}

We recently described an important role for GDNF as a neurotrophin for neonatal enteric neurons (Rodrigues et al., 2011), and both TNF $\alpha$ and IL- $1 \beta$ are able to induce GDNF expression in other cell types (Kuno et al., 2006; von Boyen et al., 2006; Saavedra et al., 2007). Therefore, we investigated the involvement of GDNF in cytokine-induced neurite outgrowth. RTPCR showed that GDNF mRNA was significantly increased by prior cytokine exposure to more than double that of control by $17 \mathrm{~h}$ (Fig. 7A). Further, the expression of GDNF protein at $24 \mathrm{~h}$ after treatment with either cytokine was significantly increased in the intracellular pool, and secreted GDNF was strongly upregulated in the culture supernatant $(>8$-fold; Fig. $7 B, C$ ), supporting a role for this neurotrophin. Vandetanib, a tyrosine kinase inhibitor that targets the GDNF receptor RET among other growth factor receptors (e.g., VEGF, EGF), was used to explore the role of GDNF in neurite outgrowth in cocultures. Pretreatment of cocultures with vandetanib $(1 \mu \mathrm{M})$ completely prevented the stimulation of neurite outgrowth caused by the addition of TNF $\alpha$ or IL- $1 \beta$ (Fig. 7D), without effect on neuron number (data not shown). Furthermore, vandetanib prevented the effect of conditioned media from cytokine-treated CSM as well as reducing axon outgrowth from either control or GDNF-treated recipient cocultures (Fig. 7E).

The evidence for GDNF as the mediator of cytokineinduced neurite growth suggested that these cytokines might also increase neuronal survival, as shown earlier for exogenous GDNF (Rodrigues et al., 2011). This was tested on freshly isolated cells from the smooth muscle/myenteric plexus that was cultured in serum-free medium, where neuronal survival is typically $50 \%$ of that in either serum-supplemented or GDNF-supplemented medium. However, cytokine-supplemented serum-free medium did not show increased neuronal number versus serum-free medium alone, whereas the positive control of direct addition of GDNF (50 $\mathrm{ng} / \mathrm{ml}$ ) increased neuronal survival nearly twofold, to a level similar to that seen in serumsupplemented medium (Fig. 7F, left). Similarly, the combination of either TNF $\alpha$ or IL- $1 \beta$ with a minimally effective level of GDNF ( $5 \mathrm{ng} / \mathrm{ml}$ ) did not achieve increased survival versus GDNF alone (Fig. 7F, right). This suggests that the cytokine-stimulated GDNF

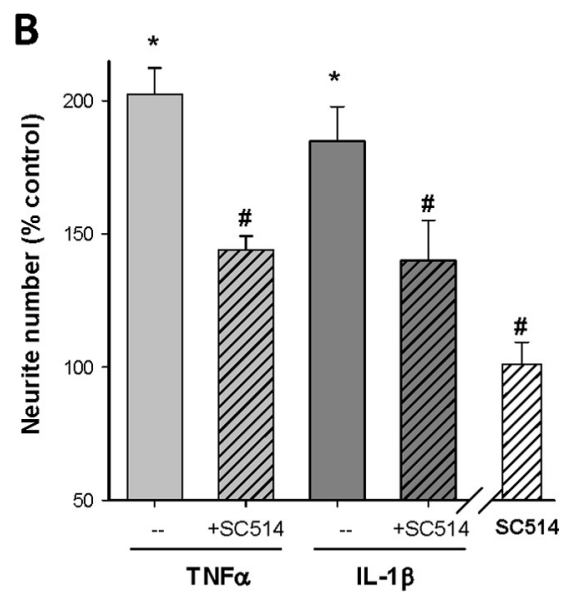

D
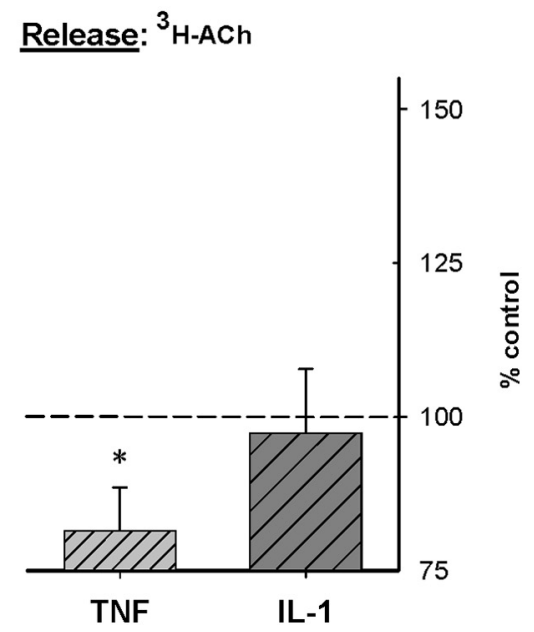

Figure 5. Cytokine-stimulated increase in neurite outgrowth is dependent on NF $\kappa$ B and affects ACh metabolism. $B$, Effect of the NF $\kappa$ B antagonists SC-514 or Bay11-7082 on cytokine-induced neurite outgrowth. Pretreatment with ( unstimulated control cultures with SC-514 or Bay $11-7082$ had no effect ( $p>0.05$ vs untreated controls; rightmost bars). $\alpha$ and IL-1 $\beta$ caused increased precursor uptake $\left(\boldsymbol{C} ;{ }^{*} p<0.05\right)$, stimulated release of $A C h$ with $80 \mathrm{~mm} \mathrm{~K}^{+}$was either reduced $\left({ }^{*} p<0.05\right)$ or not changed relative to cohort controls $(\boldsymbol{D})$.

production was ineffective in reaching the levels necessary for promotion of survival at these early time points.

To test whether cytokine-induced increases in neurite outgrowth also involved a direct action on neurons in culture, cocultures were treated with a minimally effective level of cytokine $(5 \mathrm{ng} / \mathrm{ml})$ either alone or in combination with GDNF, and both neuron and neurite number were measured $24 \mathrm{~h}$ later as above. While TNF $\alpha$ or GDNF alone caused increased neurite number ( $131 \pm 8$ and $113 \pm 8 \%$ of control, respectively), the addition of both factors resulted in a further increase in neurite outgrowth to $165 \pm 13 \%$ of control $(n=4 ; p<0.05)$. However, similar experiments with IL- $1 \beta$ and GDNF showed no synergistic effect, with neurite number not different from GDNF alone (IL- $1 \beta+$ GDNF; $140 \pm 14 \%$ of control; $n=4$; $p>0.05)$. There was no change in neuron number relative to control in any condition tested $(p>0.05)$. These outcomes suggest a distinction in the actions of TNF $\alpha$ and IL- $1 \beta$, and raising the possibility that TNF $\alpha$ but not IL- $1 \beta$ might syner- 


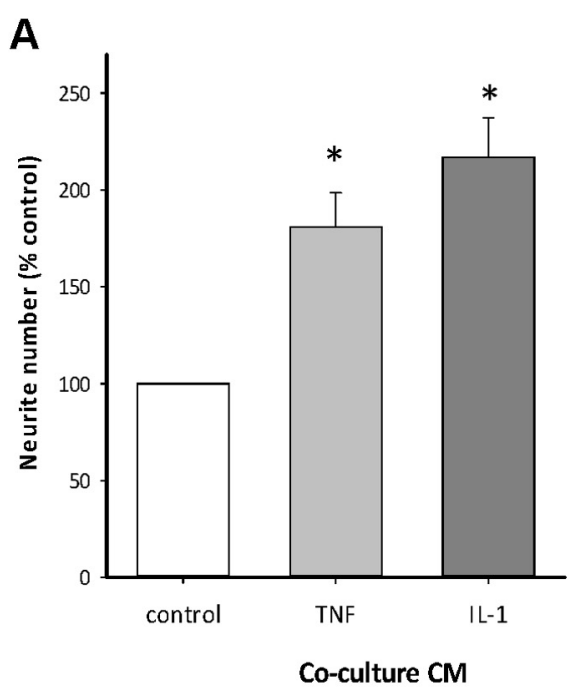

B
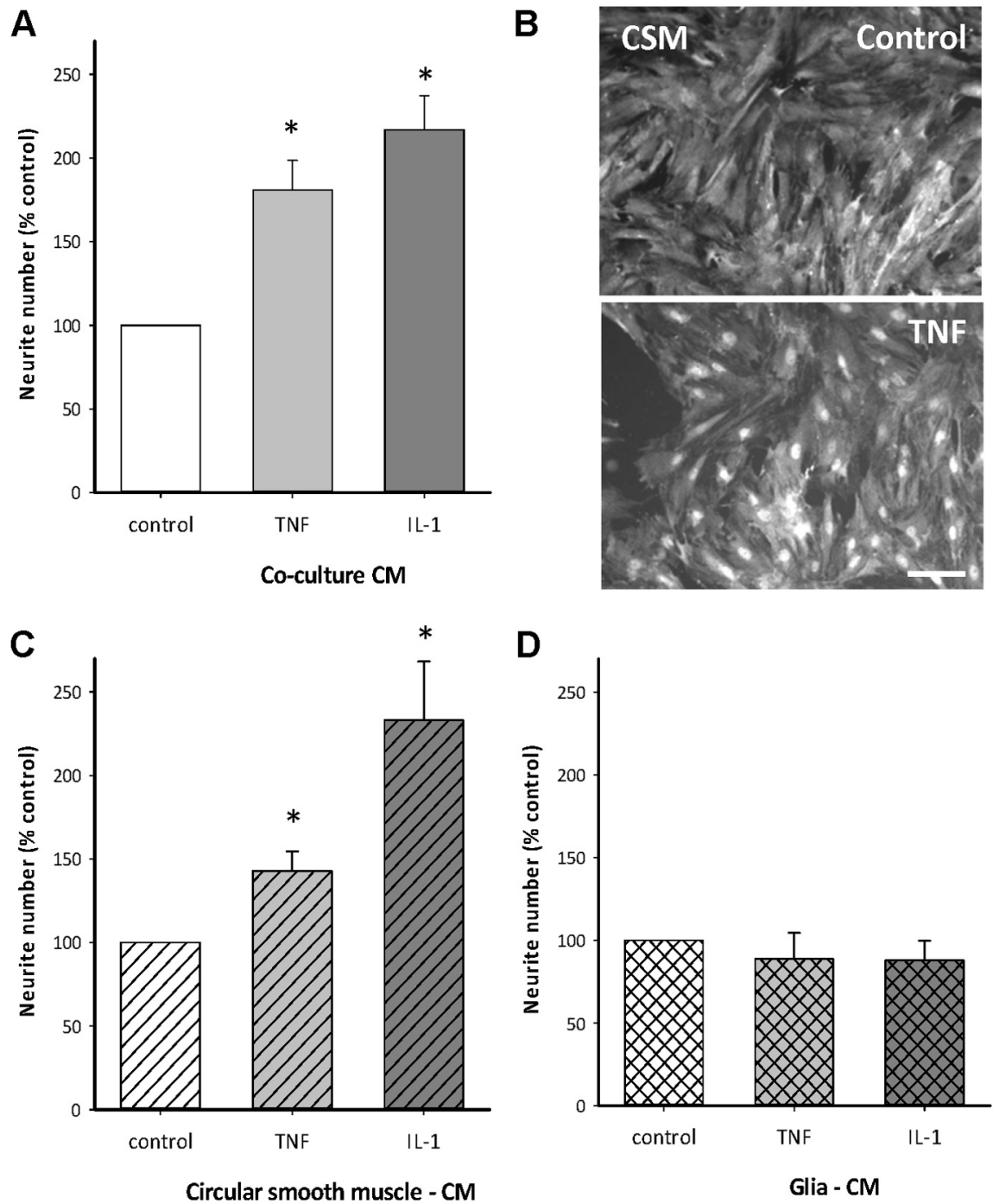

D

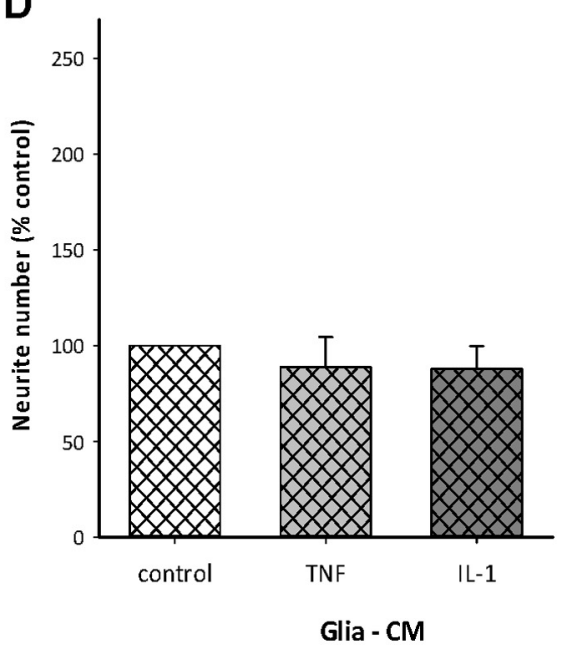

Figure 6. Cytokine stimulation of cultured intestinal CSM triggers expression of a factor promoting neurite growth. $\boldsymbol{A}$, Conditioned medium from cocultures with prior exposure to TNF $\alpha$ or IL-1 $\beta$ caused significant increase in neurite outgrowth in recipient cocultures $\left({ }^{*} p<0.05 ; n=3\right)$. $\boldsymbol{B}$, Images of cultures of CSM showing p65 translocation to the nucleus at 30 min post-cytokine stimulation. Scale bar, $100 \mu \mathrm{m}$. C, D, Conditioned medium from CSM with prior exposure to TNF $\alpha$ or IL-1 $\beta$ caused large increases in neurite outgrowth in cocultures $\left(\boldsymbol{C} ;{ }^{*} p<0.05 ; n=3\right)$ while the similar treatment of cultured enteric glia had no effect $(\boldsymbol{D})$.

gize with GDNF to further promote axon extension from enteric neurons in coculture.

\section{Immune cells, macrophages, or the inflamed tissue milieu stimulate axonal growth}

While the cytokines TNF $\alpha$ and IL- $1 \beta$ were consistently effective in influencing neurite outgrowth, neurons in vivo see such stimuli in context with numerous other factors. Therefore, we looked for evidence that processes similar to those in vitro also occurred in vivo. Since translocation of $\mathrm{p} 65$ to the smooth muscle nuclei was a critical initial response, we examined this in the mid-descending colon of control rats and at early times following initiation of TNBS-induced colitis. In the control longitudinal or circular smooth muscle layers, p65 immunoreactivity was distributed in the cytoplasm of smooth muscle cells (identified by positive staining for $\alpha$-SM actin) and absent from their nuclear regions (Fig. 8A). However, nuclear translocation of $\mathrm{p} 65$ was apparent by $12 \mathrm{~h}$ post-TNBS, with strong p65 staining of nuclei in cross sec- tions of longitudinal (Fig. 8B) or circular (Fig. 8C) smooth muscle cells in the colon.

Next, we tested whether factors derived from activated immune cells could mimic the neurotrophic effects of defined cytokines on myenteric neurons. Initially, mixed immune cells were obtained by peritoneal lavage of control rats, activated by exposure to lipopolysaccharide, washed and added to the top compartment of transwells placed over neuronal cocultures established previously. While neuron numbers were unchanged 24 later, there was a strikingly large increase in neurite number, and neurite density was increased by threefold to $306 \pm 46$ (4)\%. In parallel experiments, macrophages were purified from peritoneal cells and their effect upon addition to transwells was evaluated similarly. The neurite density at $24 \mathrm{~h}$ was identical to that caused by the mixed population, at $302 \pm 101$ (5) percentage of control (Fig. 8D).

A similar approach was used to evaluate the neurotrophic potential of the environment of the inflamed intestinal wall. Conditioned medium was obtained from explants of the smooth muscle/myenteric plexus layer of either the control or inflamed rat colon (Day 2 of TNBS-induced colitis) and evaluated for effect on neurite number in cocultures $24 \mathrm{~h}$ later. Conditioned medium from inflamed tissue strongly promoted neurite growth, nearly threefold greater than control $(p<0.05$; Fig. $8 D$ ), while no significant effect was seen with conditioned medium from control tissue. Furthermore, pretreatment of the conditioned medium from the inflamed colon with neutralizing antibodies to either IL- $1 \beta$ or TNF $\alpha$ significantly reduced the subsequent neurotrophic effect (Fig. 8D). Finally, Western blotting of tissue homogenates from the smooth muscle layer of the rat colon at Day 2 of TNBS-induced colitis showed a consistent, substantial increase in GDNF compared with control (Fig. $8 E$ ). Overall, this shows that the proinflammatory cytokines TNF $\alpha$ and IL-1 $\beta$, present in the milieu of the acutely inflamed intestine, can promote neurite outgrowth, with in vitro evidence suggesting that smooth muscle-derived GDNF is responsible.

\section{Discussion}

Animal models show that intestinal inflammation can cause both neuronal damage (Sanovic et al., 1999) and axonal growth (Lourenssen et al., 2005). The increase in axon number is rapid and extensive within the intestinal smooth muscle layers and occurs concurrently with smooth muscle cell hyperplasia, ultimately restoring innervation density to its control levels (Lourenssen et al., 2009) and showing the presence of important homeostatic mechanisms that are yet unknown. Since the complex profile of inflammatory factors in the early and subsequent events of colitis makes it difficult to interpret their specific effects on neuronal 
injury, survival, and repair, we explored this with an established coculture model, finding that the pro-inflammatory cytokines TNF $\alpha$ and IL- $1 \beta$ are not deleterious, but instead, strongly promote axonal growth from myenteric neurons.

The appearance of TNF $\alpha$ and IL- $1 \beta$ characterizes the early phase of acute inflammation in the intestine and elsewhere. Subsequently, other factors define the inflammatory profile as TH1 (e.g., TNBS-colitis), TH2 (parasitic models), or mixed (e.g., DSS colitis), categories that are useful in understanding the nature of human acute and chronic inflammatory diseases such as inflammatory bowel disease (Kaser et al., 2010; Mizoguchi and Mizoguchi, 2010). However, cytokines other than TNF $\alpha$ and IL- $1 \beta$ were ineffective in exerting a neurotrophic effect, suggesting that the early presence of these specific cytokines might be critical for later events in transmural, relatively severe inflammatory responses such as the well characterized model of TNBS-colitis used here or in the recurrent episodes of TH1 dominant inflammation seen in human Crohn's disease.

Elsewhere, the severity of neurodegenerative disease is ameliorated when the expression of TNF $\alpha$ or IL- $1 \beta$ is blocked, suggesting that the inflammatory processes stimulated by these cytokines are generally harmful and augment the damage caused by diverse triggering agents. This may occur by direct harm or by interfering with neurotrophin-mediated neuronal survival (Soiampornkul et al., 2008). However, there are also contradictory outcomes where these cytokines may improve survival, such as the mediation of hypothermia-induced neurite outgrowth by TNF $\alpha$ (Schmitt et al., 2010), or the facilitation of axon growth after controlled cortical injury in mice. In the latter, TNF $\alpha$ mRNA was upregulated at the site of damage within $6 \mathrm{~h}$ of injury but a null mutation in TNF $\alpha$ caused failure in recovery of locomotor function by $28 \mathrm{~d}$ postinjury (Oshima et al., 2009).

Increasingly refined experimental models provide valuable information as to potential mechanisms, although they can distance the outcomes from events occurring in vivo. The combination of culture models that show a beneficial outcome of cytokine presence (Araujo and Cotman, 1993) and more complex models such as organotypic brain and spinal cord slices (Boato et al., 2011) makes a compelling case that cytokines can stimulate or promote the production of neurotrophins from accessory cells. For example, IL- $1 \beta$ enhanced the
A

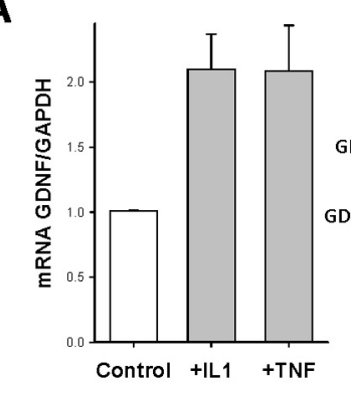

B
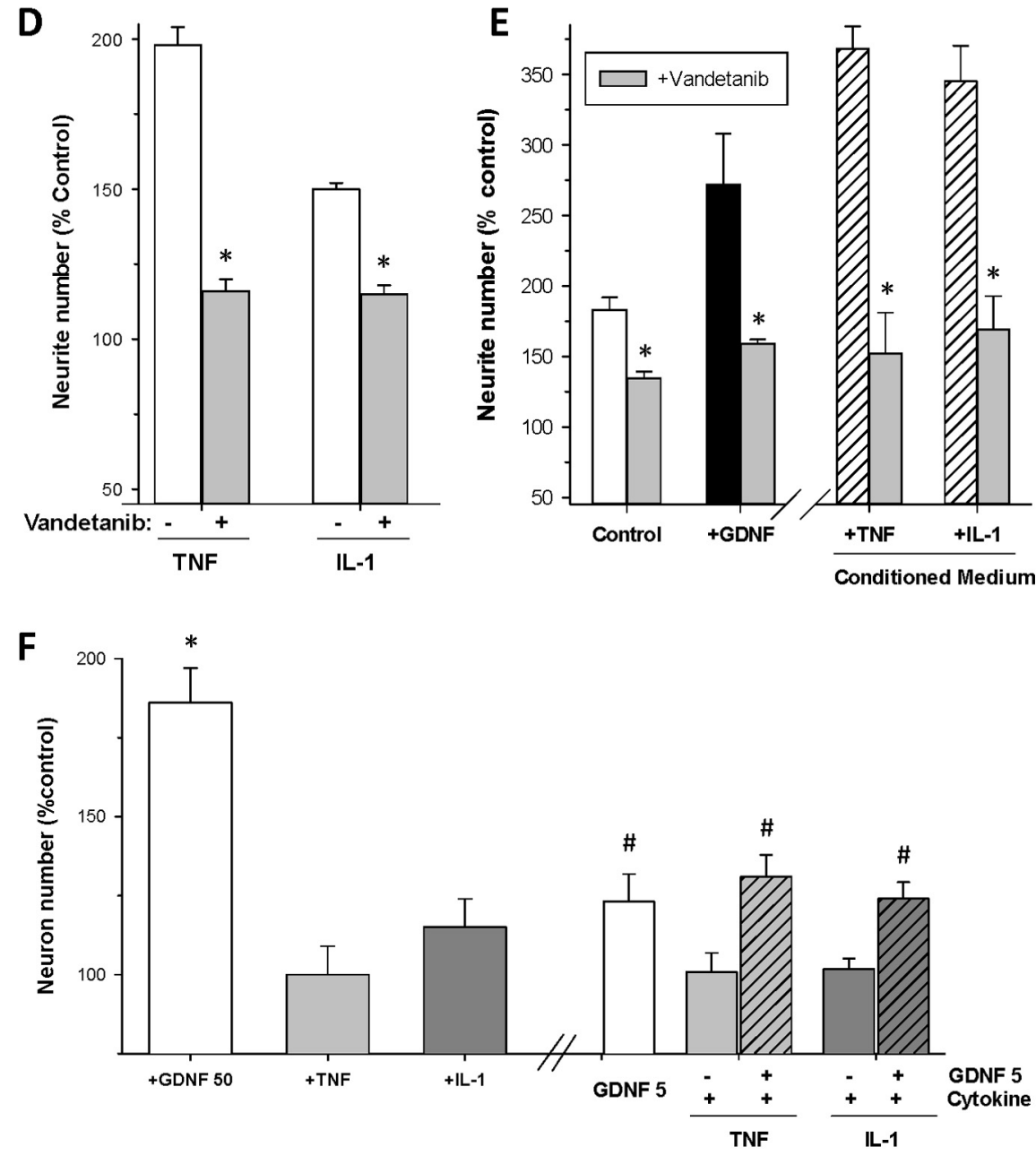

Figure 7. The cytokines TNF $\alpha$ and IL-1 $\beta$ induce neurite outgrowth via GDNF expression in cocultures and in CSM cultures. $A, q P C R$ data showing increased mRNA for GDNF in cocultures exposed to cytokines $17 \mathrm{~h}$ previously $(p<0.05 ; n=$ 3 separate experiments). $\boldsymbol{B}, \boldsymbol{C}$, Western blotting showing appearance of GDNF in cocultures at $24 \mathrm{~h}$ after treatment with TNF $\alpha$ or IL-1 $\beta$. Representative blots $(\boldsymbol{B})$ show the upregulation of intracellular GDNF and appearance of secreted GDNF in the supernatants of cytokine-treated cells. The positive control lane (GDNF) of $1 \mathrm{ng}$ of recombinant peptide showed a single band of $15 \mathrm{kDa}$. C, Quantification of Western blots showing significant increases in intracellular and secreted GDNF with cytokine treatment (all values: $p<0.05$ vs control; $n=3$ experiments). $\boldsymbol{D}, \boldsymbol{E}$, Vandetanib, an inhibitor of the RET receptor, blocks increased neurite outgrowth from cytokine-stimulated cocultures $(\boldsymbol{D})$ and also blocks the neurotrophic effect of conditioned medium from cytokine-stimulated CSM $(\boldsymbol{E})$. Vandetanib completely blocked both the effect of direct addition of GDNF $(50 \mathrm{ng} / \mathrm{ml})$ as well as the effect of conditioned medium from CSM with prior exposure to cytokines $\left({ }^{*} p<0.05\right.$; $n=3)$. $\boldsymbol{F}$, Lack of effect of cytokines on promoting survival of freshly isolated myenteric neurons. While GDNF $(50 \mathrm{ng} / \mathrm{ml})$ greatly increased survival of neurons over control (serum-free medium; $\left.{ }^{*} p<0.05\right)$, the addition of cytokines $(50 \mathrm{ng} / \mathrm{ml})$ to control medium had no effect (left). Similarly, the combination of cytokines with subthreshold levels of GDNF $(5 \mathrm{ng} / \mathrm{ml})$ did not promote its action on neuronal survival in freshly isolated cells over that of $5 \mathrm{ng} / \mathrm{ml} \mathrm{GDNF}$ alone (right; $\# p>0.05$ ). 


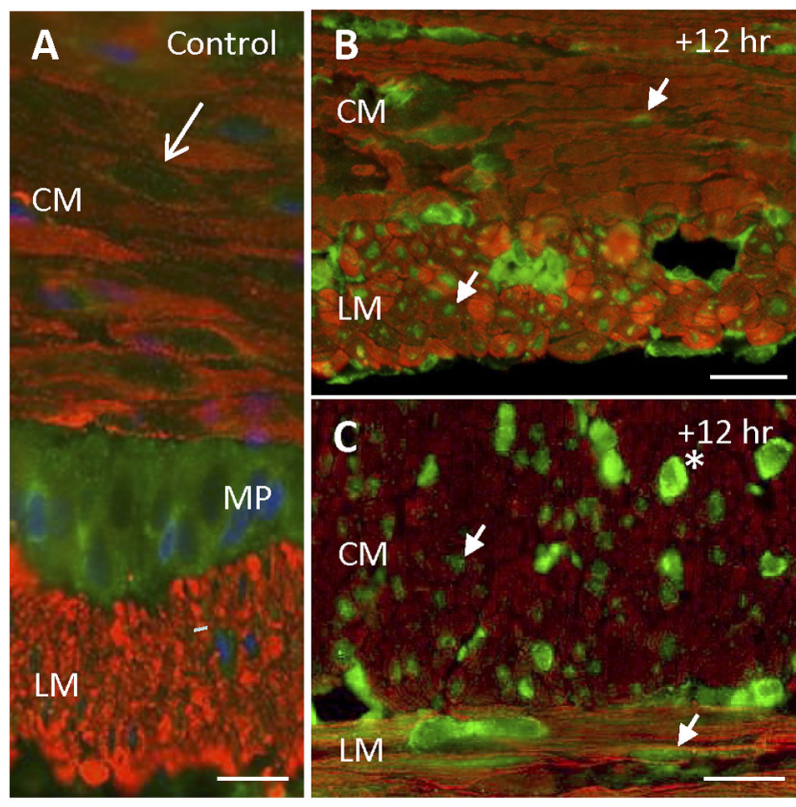

D

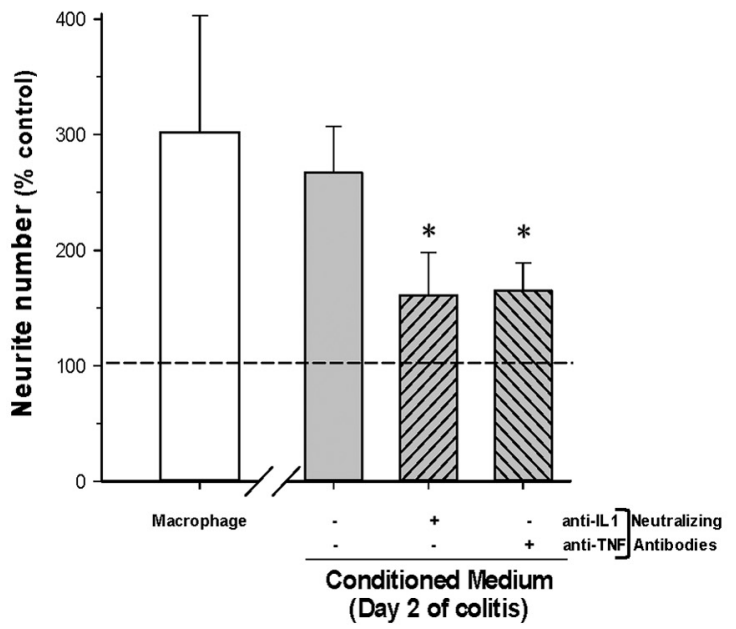

$\mathbf{E}$

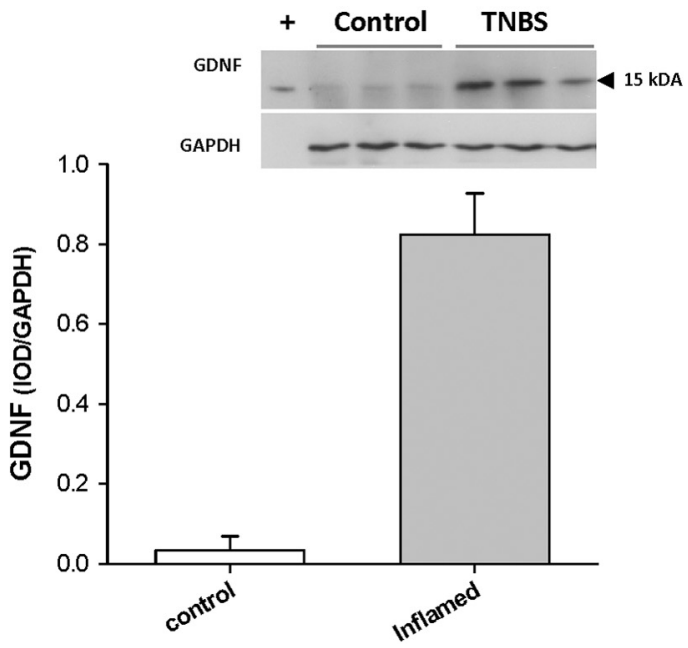

Figure 8. Evidence that inflammation causes the expression of GDNF in intestinal smooth muscle cells in vivo. Mobilization of p 65 to the nuclei of intestinal smooth muscle cells occurred early in colitis and conditioned medium from inflamed smooth muscle layers promotes neurite outgrowth in vitro, supporting a neurotrophic action of the inflammatory milieu in vivo. $\mathbf{A}-\mathbf{C}$, Representative images of immunocytochemistry for $p 65$ (green) and $\alpha$-SM actin (red) in sections of the mid-descending colon of control rats $(\boldsymbol{A})$ or at $+12 \mathrm{~h}$ of TNBS-induced colitis $(\boldsymbol{B}, \boldsymbol{C})$. In $A$, note the absence of nuclear p65 (green) in circular (CM) or longitudinal (LM) smooth recovery of sensory function after sciatic nerve injury by facilitating axon regeneration (Temporin et al., 2008), which can be related to the much earlier finding of enhanced synthesis of nerve growth factor due to macrophage-derived IL-1 $\beta$ (Lindholm et al., 1987). Overall, a case can be made for the beneficial actions of cytokines in models where non-neuronal cell types play a critical intermediate role, as supported by literature evidence in the CNS (Boato et al., 2011), the peripheral nervous system (Temporin et al., 2008; Motagally et al., 2009), and from the current study in the intestine.

Such experiments may show an underlying mechanism that involves both the direct facilitation of the action of neurotrophins as well as the stimulation of its expression. Experiments in vivo are complicated by the undeniably cytotoxic outcomes of active inflammation, where it is challenging to identify a direct relationship between cytokine and outcome. Other aspects of inflammation may also be involved, such as immune cell presence and additional inflammatory factors or extracellular matrix remodeling, with mixed beneficial and harmful outcomes. However, cytokine/neuron interactions are accessible for study in the complex coculture model used here, where smooth muscle cells, glia, and enteric neurons display key features of colitis such as neuronal death, neurite growth, and altered neurotransmitter release (Lourenssen et al., 2009; Pelletier et al., 2010).

The cytokine-induced neurotrophic effect is cell type specific via NF $\kappa$ B and GDNF expression

Although myenteric neurons expressed receptors for both $\mathrm{TNF} \alpha$ and IL- $1 \beta$, neither cytokine stimulated nuclear translocation of $\mathrm{NF} \kappa \mathrm{B}$ in these cells while doing so in adjacent smooth muscle cells. The presence of smooth muscle cells was required for cytokine-induced neurite outgrowth from myenteric neurons, and the conditioned media from intestinal smooth muscle cells, but not intestinal glia, could carry a neurotrophic signal from prior stimulation by pro-inflammatory cytokines. This led to the identification of GDNF as the cytokine-induced neurotrophic factor by mRNA and Western blotting, with functional assays showing that the neurotrophic effect was blocked by the RETreceptor blocker vandetanib and mimicked by exogenous GDNF. Such studies identified an important target-derived mechanism capable of promoting neurite outgrowth in vitro. Examination of the inflamed intestinal wall showed a parallel outcome, i.e., that a diffusible neurotrophic factor was present and reduced by neutralizing antibodies to IL- $1 \beta$ or TNF $\alpha$, indicating that intestinal smooth muscle cells can respond similarly in vivo.

The potential to drive restorative axonal growth establishes GDNF as an important factor in intestinal inflammation. Animal models have shown that diabetic peripheral neuropathy includes damage to the ENS and altered intestinal motility as described

\footnotetext{
$\leftarrow$

muscle cells (e.g., arrow). However, by $12 \mathrm{~h}$ of colitis, there is abundant nuclear labeling in smooth muscle cells of either a longitudinal $(\boldsymbol{B})$ or cross section $(\boldsymbol{C})$ of the inflamed colon (e.g. arrows). Nuclear labeling (Hoechst 333258; blue) combined with $\alpha$-SM actin was used to distinguish smooth muscle from immune cells in all cases. Nuclear labeling was omitted from the final images in $\boldsymbol{B}$ and $\boldsymbol{C}$ to allow visualization of nuclear p65 (note $\alpha$-SM actin-negative, p65positive cell in $\boldsymbol{C}_{\text {; }}^{*}$ ). MP, myenteric plexus. Scale bars: $\boldsymbol{A}, 40 \mu \mathrm{m} ; \boldsymbol{B}, \boldsymbol{C}, 20 \mu \mathrm{m}$. D, Activated macrophages (left) or conditioned medium from the smooth muscle layer of the inflamed colon at Day 2 of TNBS-colitis (right) significantly increased neurite outgrowth in cocultures. Macrophages were maintained in the top compartment of transwells while conditioned medium was added directly. Neutralizing antibodies to IL-1 $\beta$ or TNF $\alpha$ each significantly reduced the effect of Day 2 conditioned medium $\left({ }^{*} p<0.05\right.$ vs untreated $(M)$. $\boldsymbol{E}$, Western blot image and quantification of data identifying increased expression of $\operatorname{GDNF}(n=3 ; p<0.05)$ in the smooth muscle/myenteric plexus layer of the rat colon at Day 2 post TNBS-colitis.
} 
previously (Zandecki et al., 2008; Bagyanszki and Bodi, 2012). In vivo, the pathophysiological effects of hyperglycemia were associated with decreased GDNF levels, and neuronal damage both in vivo and in vitro could be reversed through exogenous GDNF (Anitha et al., 2006). Further, exogenous GDNF influences both ENS structure and intestinal function in postnatal mice (Wang et al., 2010). Overall, this points to the potential for augmented endogenous GDNF production or exogenous administration of GDNF as therapeutic strategies in intestinal disorders.

The addition of cytokines to freshly isolated myenteric neurons did not influence their survival in vitro, although recently, we showed that direct addition of GDNF strongly promoted the survival of freshly isolated myenteric neurons (Rodrigues et al., 2011), and indeed, did so in cohort-positive controls here. This illustrates the need for the sequential induction and expression of GDNF from the smooth muscle cells to achieve the neurotrophic effect, exemplified by the neurotrophic effect of smooth muscle cell-conditioned medium. In vivo, a similar sequence of events may occur, where neuronal loss is limited to the earliest times and is followed by subsequent axonal growth among the proliferative smooth muscle cells (Sanovic et al., 1999; Lourenssen et al., 2005). Overall, this builds on the importance of GDNF, following the description of its critical role in postnatal intestinal development (Gershon, 1999) and identifies it as a key factor in regulating structural plasticity in the inflamed adult intestine.

Inhibition of $\mathrm{NF} \kappa \mathrm{B}$ translocation completely blocked the neurotrophic effect in vitro, showing its crucial role, but this occurred without neurotoxicity or neurite loss relative to untreated controls. Therefore, the cytokine response constitutes the stimulation of neurite growth above a normally present baseline, potentially acting through the $\mathrm{NF} \kappa \mathrm{B}$ binding site on the promoter for human and rodent GDNF (Woodbury et al., 1998). Separately, the synergism between threshold levels of cytokines and GDNF indicates that potentiation of neuronal responsiveness may also occur, as an additional, although minor, aspect. Therefore, TNF $\alpha$ and IL1 $\beta$, but not other cytokines associated with the inflammatory response, promote the role of the neurotrophin GDNF primarily via its upregulated expression.

\section{Neurotransmitter function}

The strongly neurotrophic action of IL1 $\beta$ and TNF $\alpha$ led to rapid neurite growth and increased expression of the vesicular protein SNAP-25. This appeared universal among neuronal phenotypes, since the proportion of nNOS neurons was unchanged, with the balance represented by cholinergic neurons as reported earlier (Lourenssen et al., 2009). Increased SNAP-25 expression was matched with increased choline uptake but not with increased ACh release (expressed as a proportion of total precursor uptake), showing that functional neurotransmitter release was suppressed during the upregulation of structural components.

While it may be that additional steps of maturation of neuronal function were required, potentially over a more prolonged time course, it is well established that inflammation causes decreased release of ACh or noradrenaline from the intact intestinal wall, and that this can be mimicked with exogenous IL- $1 \beta$ or TNF $\alpha$ (Collins et al., 1989; Swain et al., 1991; Collins et al., 1992). This closely parallels the changes observed here and suggests a direct effect on neuronal metabolism, but the mechanism is unclear. The addition of TNF $\alpha(1 \mathrm{ng} / \mathrm{ml})$ to dissociated superior mesenteric ganglia reduced $\mathrm{N}$-type calcium channel activity through an NF $\kappa \mathrm{B}$-dependent mechanism as described previously (Motagally et al., 2009) and this, if present in myenteric neurons, might also contribute to the reduction in neurotransmitter me- tabolism. Earlier work showed the selective loss of the calciumbinding protein NCS-1 from the myenteric plexus of rats with colitis, additional evidence that inflammation may target the regulation of exocytotic events (Lourenssen et al., 2002). While the mechanism of altered neurotransmitter activity was not analyzed in the present study, manipulation of additional pathways may be able to address this, as in the use of anti-LIF antibodies that successfully abolished the suppression of ACh release by exogenous IL- $1 \beta$ in intact preparations (Van Assche and Collins, 1996).

\section{References}

Albina JE, Abate JA, Henry WL Jr (1991) Nitric oxide production is required for murine resident peritoneal macrophages to suppress mitogenstimulated $\mathrm{T}$ cell proliferation. Role of IFN-gamma in the induction of the nitric oxide-synthesizing pathway. J Immunol 147:144-148. Medline

Anitha M, Gondha C, Sutliff R, Parsadanian A, Mwangi S, Sitaraman SV, Srinivasan S (2006) GDNF rescues hyperglycemia-induced diabetic enteric neuropathy through activation of the PI3K/Akt pathway. J Clin Invest 116:344-356. CrossRef Medline

Araujo DM, Cotman CW (1993) Trophic effects of interleukin-4, -7 and -8 on hippocampal neuronal cultures: potential involvement of glial-derived factors. Brain Res 600:49-55. CrossRef Medline

Bagyánszki M, Bódi N (2012) Diabetes-related alterations in the enteric nervous system and its microenvironment. World J Diabetes 3:80-93. CrossRef Medline

Blennerhassett MG, Lourenssen S (2000) Neural regulation of intestinal smooth muscle growth in vitro. Am J Physiol Gastrointest Liver Physiol 279:G511-G519. Medline

Boato F, Hechler D, Rosenberger K, Lüdecke D, Peters EM, Nitsch R, Hendrix $S$ (2011) Interleukin-1 beta and neurotrophin-3 synergistically promote neurite growth in vitro. J Neuroinflammation 8:183. CrossRef Medline

Bowie A, O'Neill LA (2000) Oxidative stress and nuclear factor-kappaB activation: a reassessment of the evidence in the light of recent discoveries. Biochem Pharmacol 59:13-23. CrossRef Medline

Carlson NG, Wieggel WA, Chen J, Bacchi A, Rogers SW, Gahring LC (1999) Inflammatory cytokines IL-1 alpha, IL-1 beta, IL-6, and TNF-alpha impart neuroprotection to an excitotoxin through distinct pathways. J Immunol 163:3963-3968. Medline

Collins SM, Blennerhassett PA, Blennerhassett MG, Vermillion DL (1989) Impaired acetylcholine release from the myenteric plexus of Trichinellainfected rats. Am J Physiol 257:G898-G903. Medline

Collins SM, Hurst SM, Main C, Stanley E, Khan I, Blennerhassett P, Swain M (1992) Effect of inflammation of enteric nerves. Cytokine-induced changes in neurotransmitter content and release. Ann N Y Acad Sci 664::415-424. Medline

Diem R, Hobom M, Grötsch P, Kramer B, Bähr M (2003) Interleukin-1 beta protects neurons via the interleukin-1 (IL-1) receptor-mediated Akt pathway and by IL-1 receptor-independent decrease of transmembrane currents in vivo. Mol Cell Neurosci 22:487-500. CrossRef Medline

Dinarello CA (2010) Anti-inflammatory agents: present and future. Cell 140:935-950. CrossRef Medline

Gershon MD (1999) Lessons from genetically engineered animal models. II. Disorders of enteric neuronal development: insights from transgenic mice. Am J Physiol 277:G262-G267. Medline

Houvras Y (2012) Completing the Arc: targeted inhibition of RET in medullary thyroid cancer. J Clin Oncol 30:200-202. CrossRef Medline

Kaser A, Zeissig S, Blumberg RS (2010) Inflammatory bowel disease. Annu Rev Immunol 28:573-621. CrossRef Medline

Kindt S, Vanden Berghe P, Boesmans W, Roosen L, Tack J (2010) Prolonged IL-1beta exposure alters neurotransmitter and electrically induced $\mathrm{Ca}(2+)$ responses in the myenteric plexus. Neurogastroenterol Motil 22: 321-e85. CrossRef Medline

Klegeris A, McGeer EG, McGeer PL (2007) Therapeutic approaches to inflammation in neurodegenerative disease. Curr Opin Neurol 20:351-357. CrossRef Medline

Kuno R, Yoshida Y, Nitta A, Nabeshima T, Wang J, Sonobe Y, Kawanokuchi J, Takeuchi H, Mizuno T, Suzumura A (2006) The role of TNF-alpha and its receptors in the production of NGF and GDNF by astrocytes. Brain Res 1116:12-18. CrossRef Medline

Libby P, Warner SJ, Friedman GB (1988) Interleukin 1: a mitogen for hu- 
man vascular smooth muscle cells that induces the release of growthinhibitory prostanoids. J Clin Invest 81:487-498. CrossRef Medline

Lindholm D, Heumann R, Meyer M, Thoenen H (1987) Interleukin-1 regulates synthesis of nerve growth factor in non-neuronal cells of rat sciatic nerve. Nature 330:658-659. CrossRef Medline

Lourenssen S, Jeromin A, Roder J, Blennerhassett MG (2002) Intestinal inflammation modulates expression of the synaptic vesicle protein neuronal calcium sensor-1. Am J Physiol Gastrointest Liver Physiol 282:G1097-G1104. Medline

Lourenssen S, Wells RW, Blennerhassett MG (2005) Differential responses of intrinsic and extrinsic innervation of smooth muscle cells in rat colitis. Exp Neurol 195:497-507. CrossRef Medline

Lourenssen S, Miller KG, Blennerhassett MG (2009) Discrete responses of myenteric neurons to structural and functional damage by neurotoxins in vitro. Am J Physiol Gastrointest Liver Physiol 297:G228-G239. CrossRef Medline

Lourenssen S, Houpt ER, Chadee K, Blennerhassett MG (2010) Entamoeba histolytica infection and secreted proteins proteolytically damage enteric neurons. Infect Immun 78:5332-5340. CrossRef Medline

Lu KT, Wang YW, Yang JT, Yang YL, Chen HI (2005) Effect of interleukin-1 on traumatic brain injury-induced damage to hippocampal neurons. J Neurotrauma 22:885-895. CrossRef Medline

Marlow SL, Blennerhassett MG (2006) Deficient innervation characterizes intestinal strictures in a rat model of colitis. Exp Mol Pathol 80:54-66. CrossRef Medline

Mizoguchi A, Mizoguchi E (2010) Animal models of IBD: linkage to human disease. Curr Opin Pharmacol 10:578-587. CrossRef Medline

Motagally MA, Lukewich MK, Chisholm SP, Neshat S, Lomax AE (2009) Tumour necrosis factor alpha activates nuclear factor kappaB signalling to reduce $\mathrm{N}$-type voltage-gated $\mathrm{Ca} 2+$ current in postganglionic sympathetic neurons. J Physiol 587:2623-2634. CrossRef Medline

Nair DG, Han TY, Lourenssen S, Blennerhassett MG (2011) Proliferation modulates intestinal smooth muscle phenotype in vitro and in colitis in vivo. Am J Physiol Gastrointest Liver Physiol 300:G903-G913. CrossRef Medline

Naismith JH, Sprang SR (1998) Modularity in the TNF-receptor family. Trends Biochem Sci 23:74-79. CrossRef Medline

Neumann H, Schweigreiter R, Yamashita T, Rosenkranz K, Wekerle H, Barde YA (2002) Tumor necrosis factor inhibits neurite outgrowth and branching of hippocampal neurons by a rho-dependent mechanism. J Neurosci 22:854-862. Medline

Oshima T, Lee S, Sato A, Oda S, Hirasawa H, Yamashita T (2009) TNFalpha contributes to axonal sprouting and functional recovery following traumatic brain injury. Brain Res 1290:102-110. CrossRef Medline

Pelletier AM, Venkataramana S, Miller KG, Bennett BM, Nair DG, Lourenssen S, Blennerhassett MG (2010) Neuronal nitric oxide inhibits intestinal smooth muscle growth. Am J Physiol Gastrointest Liver Physiol 298: G896-G907. CrossRef Medline

Rodrigues DM, Li AY, Nair DG, Blennerhassett MG (2011) Glial cell linederived neurotrophic factor is a key neurotrophin in the postnatal enteric nervous system. Neurogastroenterol Motil 23:e44-e56. CrossRef Medline

Saavedra A, Baltazar G, Duarte EP (2007) Interleukin-1beta mediates GDNF up-regulation upon dopaminergic injury in ventral midbrain cell cultures. Neurobiol Dis 25:92-104. CrossRef Medline

Sanovic S, Lamb DP, Blennerhassett MG (1999) Damage to the enteric nervous system in experimental colitis. Am J Pathol 155:1051-1057. CrossRef Medline

Schmitt KR, Boato F, Diestel A, Hechler D, Kruglov A, Berger F, Hendrix S
(2010) Hypothermia-induced neurite outgrowth is mediated by tumor necrosis factor-alpha. Brain Pathol 20:771-779. Medline

Schwartz M, Solomon A, Lavie V, Ben-Bassat S, Belkin M, Cohen A (1991) Tumor necrosis factor facilitates regeneration of injured central nervous system axons. Brain Res 545:334-338. CrossRef Medline

Smith JA, Das A, Ray SK, Banik NL (2012) Role of pro-inflammatory cytokines released from microglia in neurodegenerative diseases. Brain Res Bull 87:10-20. CrossRef Medline

Soiampornkul R, Tong L, Thangnipon W, Balazs R, Cotman CW (2008) Interleukin-1beta interferes with signal transduction induced by neurotrophin-3 in cortical neurons. Brain Res 1188:189-197. CrossRef Medline

Stanzel RD, Lourenssen S, Nair DG, Blennerhassett MG (2010) Mitogenic factors promoting intestinal smooth muscle cell proliferation. Am J Physiol Cell Physiol 299:C805-C817. CrossRef Medline

Swain MG, Blennerhassett PA, Collins SM (1991) Impaired sympathetic nerve function in the inflamed rat intestine. Gastroenterology 100:675-682. Medline

Temporin K, Tanaka H, Kuroda Y, Okada K, Yachi K, Moritomo H, Murase T, Yoshikawa H (2008) Interleukin-1 beta promotes sensory nerve regeneration after sciatic nerve injury. Neurosci Lett 440:130-133. CrossRef Medline

Uesaka T, Nagashimada M, Yonemura S, Enomoto H (2008) Diminished Ret expression compromises neuronal survival in the colon and causes intestinal aganglionosis in mice. J Clin Invest 118:1890-1898. CrossRef Medline

Van Assche G, Collins SM (1996) Leukemia inhibitory factor mediates cytokine-induced suppression of myenteric neurotransmitter release from rat intestine. Gastroenterology 111:674-681. CrossRef Medline

Verdu EF, Collins SM (2005) Irritable bowel syndrome and probiotics: from rationale to clinical use. Curr Opin Gastroenterol 21:697-701. CrossRef Medline

Vermeire S, Van Assche G, Rutgeerts P (2012) Classification of inflammatory bowel disease: the old and the new. Curr Opin Gastroenterol 28:321326. CrossRef Medline

von Boyen GB, Steinkamp M, Geerling I, Reinshagen M, Schäfer KH, Adler G, Kirsch J (2006) Proinflammatory cytokines induce neurotrophic factor expression in enteric glia: a key to the regulation of epithelial apoptosis in Crohn's disease. Inflamm Bowel Dis 12:346-354. CrossRef Medline

Wang H, Hughes I, Planer W, Parsadanian A, Grider JR, Vohra BP, KellerPeck C, Heuckeroth RO (2010) The timing and location of glial cell line-derived neurotrophic factor expression determine enteric nervous system structure and function. J Neurosci 30:1523-1538. CrossRef Medline

Wells RW, Blennerhassett MG (2004) Persistent and selective effects of inflammation on smooth muscle cell contractility in rat colitis. Pflugers Arch 448:515-524. Medline

Woodbury D, Schaar DG, Ramakrishnan L, Black IB (1998) Novel structure of the human GDNF gene. Brain Res 803:95-104. CrossRef Medline

Yang CM, Luo SF, Wang CC, Chiu CT, Chien CS, Lin CC, Hsiao LD (2000) Tumour necrosis factor-alpha- and interleukin-1beta-stimulated cell proliferation through activation of mitogen-activated protein kinase in canine tracheal smooth muscle cells. Br J Pharmacol 130:891-899. CrossRef Medline

Zandecki M, Vanden Berghe P, Depoortere I, Geboes K, Peeters T, Janssens J, Tack J (2008) Characterization of myenteric neuropathy in the jejunum of spontaneously diabetic BB-rats. Neurogastroenterol Motil 20:818828. CrossRef Medline 